\title{
SOLUÇŌES PACÍFICAS DE LITÍGIOS NA AMÉRICA LATINA: RETROSPECTIVA 1988
}

\author{
Guido Fernando Silva Soares \\ Professor Associado de Direito Internacional da Faculdade de Direito da USP
}

\begin{abstract}
Resumo: Trata-se de analisar, nos últimos 20 anos, a situação dos conflitos regionalizados na América Latina, e das maneiras de sua solução pacífica, com o recurso aos denominados meios de soluções extrajudiciários, não previstos no sistema jurídico da Organização dos Estados Americanos, OEA. São repassados os institutos dos bons ofícios, da mediação, da conciliação e da arbitragem, com ênfase na atuação dos arranjos diplomáticos e das organizações de integração econômica regional. Em um estudo tópico, examinam-se as cláusulas compromissórias (arbitrais) tais quais existentes nos tratados internacionais subscritos pelo Brasil, o que pode ser um indicativo de como o Brasil tem entendido a solução arbitral nas suas relações internacionais.
\end{abstract}

Summary: This is a general analysis of the last 20 years of regional conflicts in Latin America, as well as the means which were used to deal with them, such as the so-called extrajudicial means, not included within the framework of the Organization of American States, OAS. There are considerations about mediation, conciliation and arbitration, with emphasis on the diplomatic negociations and on the regional economic integration organization. In a opic study, there is an analysis of the arbitral clauses (compromissory closes) such as those existing in the international agreements subscribed by Brazil, which can be good indicators of how Brazil has provided for the Country's international relations.

Unitermos: Soluçōes Pacíficas de Litígios Internacionais. Relações Internacionais na América Latina, fora do contexto da OEA. Arbitragem no Brasil (cláusulas arbitrais em tratados internacionais vigentes). Organizaçōes Internacionais de integração econômica na América Latina, como soluções pacíficas de controvérsias.

RESUMO: I - Introdução: Delimitação do Tema. 2 - Os Modos de Soluções Pacíficas de Controvérsias e Seu Hermetismo. 3 - Soluçōes Pacíficas de Controvérsias: Impacto das Organizações Internacionais. 4 - Um Estudo de Caso: Soluçōes Arbitrais Previstas em Tratados em que o Brasil é Parte. 5 - Conclusōes. Bibliografia.

\section{I - Introdução: Delimitação do Tema}

Do temário do Seminário "Integração Solidária para a Manutenção da Paz na América Latina", em Caracas, organizado pelo "Instituto de Altos Estudios 
de América Latina" da Universidade Simón Bolivar de Caracas, constava o tema: Exame dos Principais Tratados Bilaterais e Multilaterais Vigentes entre Países Latino-Americanos (Não-Pertencentes ao Sistema Interamericano) sobre Soluções Pacíficas de Conflitos, com Ênfase Especial em Seu Possível Hermetismo e Suas Aplicações. Outros relativos à mesma preocupação, quanto aos mecanismos de integração solidária e soluçōes pacíficas na região, igualmente figuravam da pauta do referido seminário, e tinham sido precedidos de vários estudos preliminares encetados, em particular, pela "Associación de Investigaciones y Especialización sobre Temas Iberoamericanos", AIETI, de Caracas.

Com a finalidade de bem distribuir as tarefas dos pesquisadores e dos resultados de seus trabalhos, o eminente Prof. Dr. Miguel Angel Burelli Rivas, Diretor do mencionado "Instituto de Altos Estudios de América Latina" de Caracas, remeteu o documento "Descripción Substantiva del Proyeto", que deveria servir de parâmetro para as comunicaçōes. $\mathrm{Na}$ verdade, qualquer análise da situação política na América Latina deve levar em consideração a existência e atuação da Organização dos Estados Americanos, OEA, ainda que seja para concluir sobre sua inoperância; o presente estudo, não estrará na análise da atuação da OEA, nem pretenderá sequer examinar as causas de sua inoperância na região, tarefa a outros atribuída.

Já a própria caracterização da América Latina, como uma entidade monolítica, pode levar a distorçōes e simplificaçōes perigosas, numa análise da política internacional atual; muito mais sujeito a erros e generalizaçōes abusivas, pretender vislumbrar um particularismo no Direito Internacional Público, quando se trata de fenômenos regionais, ou ainda, uma eventual contribuição do mundo latino-americano ao capítulo das soluçōes pacíficas de litígios entre Estados. Isto posto, ater-nos-emos aos termos da "Descipción Substantiva del Proyeto" que assim dispōem:

El mantenimiento de la paz preocupa a todos los países del área. Casi todos mantienen conflictos de envergadura y cada vez más generalizado y diversificados (v. Wolf Grabendorf, Zwischenstaatliches Konfliktverhalten und Regionales Konfliktpotential in Lateinamerika, Stiftung Wissenschaft und Politik... noviembre (1980). Generalmente se lo ha enfocado desde el punto de vista jurídico-normativo, y por eso se ha considerado que cuanto má hermético es un tratado, mayores posibilidades existen de que se logre un arreglo satisfactorio en una situación conflictiva. Sin embargo, ejemplos múltiples y muy caracterizados (el Pacto de Bogotá es tal vez el mejor) demuestra que los Estados latinoame- 
ricanos son reacios a admitir procedimientos que suponen el consentimiento anticipado a soluciones que dictará obligatoriamente un órgano ajeno a las Partes. (v. Michael A. Morris y Victor Millán, Controlling Latin American Conflicts, Boulder, Colorado, Westview, 1984).

Segundo o extenso título enunciado para o tema, trataremos de examinar os seguintes aspectos:

a) os principais tratados bilaterais e multilaterais vigentes nos Países latino-americanos, tratados esses que não se enquadram no sistema interamericano;

b) dos tratados cuja vigência se enquadram no ítem anterior, serão examinados aqueles que, de forma direta (tratados sobre soluçōes pacíficas de conflitos) ou de forma indireta (tratados sobre comércio, amizade e consulta, navegação, etc., que contenham cláusulas de soluçōes pacíficas de conflitos), consagram o recurso às soluçōes pacíficas de controvérsias;

Sendo assim, tomada a qualificação do que seja integrante do sistema interamericano, ficam excluídos do presente trabalho os seguintes temas, que são bastante relevantes para o estudo das soluçōes pacíficas de controvérsias: a) a análise da Carta da OEA e sua compatibilidade com as soluções pacíficas constantes da Carta da ONU; b) o inteiro teor do Tratado Interamericano de Soluçōes Pacíficas; c) os mecanismos do TIAR; d) as soluçōes elaboradas sob a égide da OEA ou com sua efetiva participação, seja em soluções multilaterais formais ou informais, seja em soluções de caráter bilateral.

O segundo aspecto (tratados multilaterais ou bilaterais que consagram a solução pacífica de controvérsias), respeitado o limite anteriormente posto, faznos rejeitar um exame dos outros tratados interamericanos igualmente relevantes para o tema, tais as convençōes relativas a asilo diplomático e a asilo territorial (Caracas, durante a X Conferência Interamericana, em 28 de março de 1954), a Convenção Internacional sobre a Condição dos Estrangeiros (VI Conferência Interamericana, Havana, em 28 de fevereiro de 1928), a Declaração Americana dos Direitos e Deveres do Homem (IX Conferência Panamericana de Bogotá, em 1/ 43) a Convenção Americana sobre Direitos Humanos (San José da Costa Rica, em 22 de novembro de 1969) e um sem número de atos internacionais votados nas reuniōes ordinárias e extraordinárias dos órgãos da OEA.

O terceiro aspecto (competência e jurisdição dos órgãos de soluçōes pacíficas, inter partes e inter alios) pelas mesmas razōes já examinadas, não poderá tratar do papel de mediador, conciliador, condutor de negociaçōes nos bons ofícios, que o Secretário Geral da OEA, por força dos tratados interamericanos vigentes e por força dos costumes regionais, possui "pleno jure". Tam- 
bém não serão estudadas as possibilidades de atuação das reuniōes "ad hoc" dos Ministros das Relaçōes Exteriores dos Estados Interamericanos, na solução pacífica de controvérsias. Neste particular, as Reuniões de Consultas que se têm verificado, Grupo de Contadora, a respeito das propostas de paz na América Central (Colômbia, México, Panamá e Venezuela), o Grupo de Apoio Contadora Support Group (Argentina, Brasil, Peru e Uruguai), nos períodos de 1984 a 1987, considerados como ações de mediadores, assim como o denominado "Consenso de Cartagena" (Argentina, Bolívia, Brasil, Chile, Colômbia, República Dominicana, Equador, México, Peru, Uruguai e Venezuela), comunicado dos Ministros das Relaçōes Exteriores e dos Responsáveis pelas Finanças dos Países envolvidos, de 22 de junho de 1984, relativo à dívida externa e desenvolvimento econômico, representam atuações diplomáticas modernas e muito mais atuantes, que os tradicionais canais existentes na OEA; sendo assim, merecerão destaque como meios de solução pacíficas de controvérsias, que não se enquadram no sistema interamericano.

c) no exame dos textos dos tratados globais de solução pacífica de controvérsias ou das cláusulas contidas em outros tratados, a ênfase será colocada na questão da competência e jurisdição dos órgãos das soluções pacíficas porventura estabelecidos naqueles instrumentos, seja no que diz respeito às partes contratantes, seja no que respeita a terceiros;

d) segundo as tendências modernas do Direito Internacional (Jessup, McNair, Ch. de Vischer, Fr. Rigaux), na análise das relações entre os Estados, merece lugar privilegiado a posição das relações comerciais entre particulares submetidos a leis de Estados diferentes e, ainda, outro tipo mais moderno, as relaçōes entre Estados e particulares estrangeiros, relações essas que afetam diretamente o entendimento pacífico entre os Estados.

O primeiro aspecto (tratados que se encontram fora do sistema interamericano), exige uma definição do que se entende, no presente trabalho, por sistema interamericano. Na verdade, no capítulo de soluções pacíficas de conflitos, a própria história e o desenvolvimento orgânico e funcional da OEA demonstram a busca de mecanismos políticos e diplomáticos para evitar-se um confronto bélico entre os Estados participantes das organizaçōes antecessoras da OEA, (a então União Pan-Americana). No regime anterior à modernização do sistema interamericano, em particular no Entre-Guerras, devem ser mencionados os esforços que resultaram durante a reunião da VI Conferência Panamericana de 1928, em Havana, na qual se assinou o Código de Direito Internacional Privado (Código Bustamente) e várias outras convenções (direitos e deveres dos Estados, funcionários diplomáticos) que foram desmembradas do Projeto Epitácio Pessoa de codificação do Direito Internacional Público; de igual importância, deve-se mencionar no mesmo Entre-Guerras, a VIII Conferência Panamericana de 1938, em Lima, que, dentre as 12 declaraçōes aprovadas, adotou a Declaração sobre a Solidariedade Continental Americana, gênese do sistema 
de solidariedade que será consagrado no Tratado Interamericano de Assistência Recíproca, TIAR, assinado no Rio de Janeiro a 2 de setembro de 1947, portanto, já no sistema da moderna OEA ${ }^{(1)}$.

O sistema interamericano, na verdae, pode ser definido por um tripé, construído sobre três tratados elaborados após a Segunda Guerra Mundial, em conformidade com a instalaçāo do sistema de segurança coletiva das Nações Unidas, com a vigência da Carta de São Francisco de 26 de junho de 1945: a Carta da Organização dos Estados Americanos, assinada no decurso da IX Conferência Interamericana de Bogotá de 30 de abril de 1948 (emendada pelo Protocolo de Buenos Aires de 1967, subscrito durante a Terceira Conferência Interamericana Extraordinária, em vigor a partir de 27/II/1/170); o Pacto de Bogotá, Tratado Interamericano de Soluções Pacíficas, assinado no decurso da mesma IX Conferência Interamericana de Bogotá; e o Tratado Interamericano de Assistência Recíproca, TIAR, ou Tratado do Rio de Janeiro, assinado nessa Cidade, a 2 de setembro de 1947. Considera-se, pois, como integrante do sistema interamericano: a) os Estados pertencentes à OEA, nas suas relações recíprocas; b) as soluçōes elaboradas no marco institucional da OEA, seja por iniciativa e atuação dos Estados dentro das normas da OEA, seja por iniciativa e atuação dos funcionários investidos em funçōes de órgãos de soluçōes pacíficas de controvérsias (com ênfase nas funçōes de bons ofícios e mediação do Secretário-Geral da OEA); c) as atuaçōes dos Estados ou da OEA em relação a Estados não membros da mesma, mediante a aplicação das normas específicas dos tratados interamericanos a Estados terceiros (como foi o caso questionável da importância das Decisões do Conselho da OEA, na Crise dos Mísseis Nucleares em Cuba, onde se verificou a oposição Kennedy-Khruschov, em $1962^{(2)}$.

O quarto aspecto, (relações entre particulares e entre particulares estrangeiros e Estados situados na América), apresenta particular interesse no presente estudo, especialmente levando-se em conta a ênfase que se pretende quanto ao hermetismo dos atos normativos e sua aplicação aos Estados envolvidos. Na verdade, conforme a "Descripctión Sustantiva del Proyecto", existe uma relação entre hermetismo de soluçôes, de um lado, e de outro, as possibilidades de executar-se a medida de solução de controvérsia criada pelo ato normativo. Também se pretende demonstrar que a razão de tal correlaçāo entre hermetismo e aplicabilidade, reside na resistência dos Estados latino-americanos de admitir soluções baseadas em procedimentos que suponham o consentimento antecipado à jurisdição de órgãos alheios às Partes. Tais temores, em que pese a atual situação econômica do mundo em geral, onde o fluxo dos capitais

(1) Veja-se: M.J. Yepes, Philosophie du Panaméricanisme et Organisation de la Paix, Neuchâtel, Editions de la Baconnière, $194 \mathrm{l}$.

(2) Veja-se: J.G. Stoessinger, The Might of Nations, World Politics in Our Times, Random House, Nova York, 1967, em particular, pág. 165 e ss. 
privados é muito mais significativo que os fluxos de capitais controlados pelos Estados, podem representar uma ameaça à soberania dos Estados, soberania no sentido seiscentista de J. Bodin, mas não conseguem sequer disciplinar as relaçōes de um mundo de relaçöes comerciais internacionais, que se regem por normas próprias (a lex mercatoria) muitas vezes insusceptíveis de controle pelos Estados; enquanto, no sistema interamericano, demoram-se décadas para regulamentar a arbitragem comercial internacional, o que, enfim, foi timidamente feito no México, em 1968, (Segunda Conferência Interamericana sobre Arbitragem Comercial), que ressuscitaria a Comissão Interamericana de Arbitragem Comercial, criada em 1933, por ocasiāo da Sétima Conferência Interamericana de $1933^{(3)}$. Enfim, tão somente em 30 de janeiro de 1975, durante a Conferência Especializada Interamericana sobre Direito Internacional Privado, no Panamá, foi assinada a Convenção Interamericana sobre Arbitragem Comercial Internacional, por delegados de doze países, "sempre relutantes em subscreverem atos internacionais que impliquem na transformação de seu direito privado interno"(4). Ora, se pensarmos que tão somente nos dias atuais (1986) nove países latino-americanos ratificaram a Convenção do Panamá (Chile, Costa Rica, El Salvador, Honduras, México, Panamá, Uruguai e Venezuela), na qual se encontram ausentes a maioria dos Países do Continente Americano, pode-se constatar a inoperância do sistema interamericano em elaborar normas relativas à arbitragem comercial internacional. Por outro lado, é igualmente notável que existem ausências importantes na Convenção de Nova York de 10 de junho de 1958 "sobre homologação e execução de laudos arbitrais estrangeiros", pois do Continente Americano, tão somente ratificaram a mesma: Chile, Colômbia, Cuba, Equador, Guatemala, Haiti, México, Panamá, Trinidad-Tobago, EUA e Uruguai; quanto ao Brasil, é o único país da América Latina (talvez do mundo) a ainda ser parte do Protocolo de Genebra de 1923, "relativo a cláusulas de arbitragem"(5).

No capítulo das relações entre Estados e particulares estrangeiros, a omissão do sistema interamericano é ainda mais lamentável. Na Convenção BIRD, Convenção sobre Resolução de Controvérsias Relativas a Inversōes entre Estados e Particulares, aprovada pela Assembléia Geral da ONU em 1965 (Recueil des Traités da ONU, no 8.359), sem embargo da presença crescente dos países novos da Ásia e África, não participam Países da América Latina,

(3) Veja-se: "Report of the Vice President of the Interamerican Commercial Arbitration Commission", Donald B. Straus, na VI Conferência Interamericana sobre Arbitragens Comerciais, realizada no Rio de Janeiro, em 5/6 de abril de 1976.

(4) Apud "Introdução Histórica ao Estudo das Soluções Pacíficas de Litígios e das Arbitragens Comerciais Internacionais", de Guido F.S. Soares, in Revista da Faculdade de Direito da Universidade de São Paulo, São Paulo, 1976, vol. LXXI, pág. 163 ss.

(5) Informaçōes apud Frank E. Nattier "International Commercial Arbitration in Latin America: Enforcement of Arbitral Agreements and Awards" in Texas International Law Journal, 1986, vol. 21, nº 3, p. 405. 
além da Guiana, Jamaica e Trinidad-Tobago. Ora, se tivermos em mente que o Centro Internacional para Solução de Disputas sobre Inversões, criado na Convenção BIRD, é um dos foros mais adequados a resolver controvérsias relativas a inversōes de capitais privados na América Latina e que tais capitais são a grande fonte de endividamento externo da região, pouco se compreende sobre a relutância dos Países da América Latina em ficar à margem do referido Centro do BIRD e continuar apegada a uma concepção ultrapassada de soberania, ligada a uma teoria irrealista no Século XX (as doutrinas Drago e Calvo válidas para impedir as intervenções diretas dos Estados nos negócios internos de outro, com o fito de proteger inversōes de seus particulares, fenômenos que hoje não mais existem, à vista da força das multinacionais e de outros meios mais poderosos e menos arriscados que as intervenções armadas diretas).

Finalmente, como necessidade preliminar, deseja-se no presente trabalho esclarecer que a análise do assunto se fez a partir da posição de um analista brasileiro, que não teve acesso à documentação já existente e preparada pela "Asociactión de Investigación y Especialización sobre Temas Iberoamericanos" (AIETI) conforme consta da Descripción Sustantiva del Proyecto, que o autor recebeu com carta do Sr. Dr. Miguel Angel Burelli Rivas, DD. Diretor do Instituto de Altos Estudios da América Latina da Universidade Simón Bolívar, em 6 de julho de 1988. Sendo assim, o presente estudo deve refletir uma visão pessoal de um analista brasileiro, sem acesso a um levantamento global de documentação nos países latino-americanos e nos pertencentes ao Continente.

\section{Os Modos de Soluções Pacíficas de Conflitos e Seu Hermetismo}

Modos de soluçōes pacíficas de conflitos são os instrumentos elaborados pela cultura do homem, através de sua história, para prevenir o confronto armado direto ou a utilização de seu eventual emprego (ameaças indiretas ou diretas, que na linguagem moderna se denomina: dissuasão). Numa visão ampla, podese afirmar que a própria norma do direito seja ela uma forma de solução pacífica de conflito, na medida em que determina padrōes de comportamento desejáveis pela sociedade (norma primária, ou endonorma), com a exclusão de outros, tidos por ilegais ou injustos, e que, portanto, devem ser repelidos por um sistema secundário de sanções legitimadas pela lei (norma secundária ou perinorma). Numa visāo técnica, contudo, aqueles modos de solução de controvérsias são os instrumentos específicos fixados em lei, aos quais se recorrem para evitar uma confrontação: no direito interno dos Estados, os instrumentos criados pela Constituição dos mesmos e determinados pelas leis ordinárias: a atuação do Poder Judiciário, a atuação quase-judiciária dos outros órgãos do Estado (do Legislativo e da Administração) e as soluçōes extrajudiciárias elaboradas pelas partes, às quais a lei admite força de solucionar conflitos (a transação, a solução arbitral de litígios privados, a desistência de direitos, a negociação e rene- 
gociação de contratos, negócios, etc.); no direito internacional, em particular devido à inexistência de um legislador supranacional único, à imperfeição das normas secundárias (pela inexistência de um Poder de aplicar sançöes existentes), pela complexidade na existência de sujeitos soberanos, os meios pacíficos são muito mal fixados em lei, alguns apenas esquematizados e outros mal elaborados.

$\mathrm{Na}$ verdade, nas relaçōes internacionais, não se pode, como nos direitos internos, buscar uma qualificação do conflito, para depois, buscar-se o meio de solucioná-los. No Direito Internacional, o formalismo dos meios de solução pacífica de conflitos pode ser antes uma dificuldade para sua utilização. Por tais motivos, a definição e classificação dos meios pacíficos de conflitos são imprecisas, variam de autor para autor, de diplomacia para diplomacia de Estados, de séculos para séculos. A própria definição dos conflitos e dos meios de solucioná-los, quando contida em tratados internacionais, pode ser uma definição passageira, susceptível de sofrer as variaçōes conceituais e ideológicas contidas naqueles tratados definidores.

O Século XX tem sido pródigo em desafiar a tipologia dos meios pacíficos de solução de conflitos: de um lado, viu surgir conflitos novos, inexistentes à época em que os meios pacíficos clássicos foram elaborados (a dissuasão nuclear, os conflitos de natureza econômica criados por particulares e que arrastam os Estados, os conflitos nascidos da intervenção econômica do Estado na esfera da economia interna e do comércio internacional); por outro lado, elaboraram-se soluções novas, aparecidas no seio das organizaçōes internacionais, que, ou vieram reformular a tipologia existente nos séculos anteriores (a mediação e os bons ofícios, que ganham novas formas com as atuaçōes dos altos funcionários dos organismos internacionais) ou fazer aparecer novas (em particular, a soluçāo judicial, nos organismos de integraçāo econômica, a exemplo da Corte de Justiça das Comunidades Econômicas Européias, ou a solução revolucionária da criação de sociedades comerciais internacionais interestatais, do tipo ITAIPU-BINACIONAL, ou comerciais internacionais com a participação indireta dos Estados, do tipo URENCO, LATINEQUIPE...).

Sendo assim, a tentativa de classificar os conflitos internacionais em conflitos de natureza política (nos quais os interesses conflitantes teriam origem em fatos ainda não regulados pela norma jurídica) ou de natureza jurídica (originários de uma interpretação conflitante de uma norma jurídica pré-existente), à maneira de Verdross e H. Kelsen, embora seja sedutora do ponto de vista acadêmico, não representa nenhuma solução para sua aplicação: na verdade, a classificação tem por finalidade não só conhecer a tipologia dos conflitos, mas buscar a solução adequada, ou em outras palavras, a classificação deve ter uma finalidade de dar os instrumentos adequados à sua solução.

Mesmo assim, reconhecendo a dificuldade do tema, pode-se, como o faz o 
Prof. Dr. Celso D. de Albuquerque Mello ${ }^{(6)}$, classificar os modos de solução pacífica dos litígios internacionais em: a) diplomáticos (1 - negociaçōes diplomáticas, bilaterais e multilaterais; 2 - serviços amistosos; 3 - mediação; 4 bons ofícios); b) jurídicos (1 - comissão de inquérito; 2 - conciliação; 3 - arbitragem; 4 - solução judiciária); c) políticos (soluçōes dadas pelas organizações internacionais). $\mathrm{O}$ mesmo Prof. Albuquerque Mello reconhece a dificuldade na classificação dos institutos, ao reconhecer que os modos políticos nāo deixam de ser modos diplomáticos, como ocorre com a consulta. "A conciliação pode ser um modo jurídico ou político. Entretanto, colocamos nesta classificação a solução dos litígios internacionais no âmbito das organizações internacionais que têm um procedimento próprio e preferimos, assim, estudá-la em separado" (op. cit., p. 986, nota 4).

Admitida a correlação entre hermetismo das soluções pacíficas de controvérsia e a eficácia dos meios na efetiva solução dos conflitos, pode-se dizer que quanto mais formal é o modo de solução pacífica de controvérsia (por implicar numa aceitação prévia de sua instituição, de seu funcionamento, dos resultados de sua atuação no mundo formal) mais susceptível de se tornar eficaz e produzir seus efeitos no mundo prático (mais exeqüível é sua solução por parte dos Estados envolvidos). Os estudos sobre a eficácia das soluções mais perfeitas e formais existentes nas relaçōes humanas, ou seja, a eficácia das decisōes do Poder Judiciário no interior dos Estados, têm merecido atenção da doutrina internacional moderna. Não foi por outra razão que a Association Henri Capitant des Amis de la Culture Juridique Française, nas "Journées Françaises de Paris et Aix-en-Provence" em 1985, propôs uma investigaçāo internacional sobre o tema "L'Effectivité des Décisions de Justice"(7), em face da perplexidade quanto à efetiva atuação na vida da sociedade das decisōes judiciárias, em outras palavras, aos efeitos reais das sentenças judiciárias no mundo prático!

Isto posto, pode-se dizer que existe uma escala de formalismo crescente e, portanto, de possível acatamento de suas soluçōes no mundo real por parte dos Estados envolvidos, expressa na seguinte gradaçāo: negociaçōes diplomáticas multilaterais, negociaçōes diplomáticas bilaterais, serviços amistosos, mediação, bons ofícios, comissāo de inquérito, conciliação, arbitragem e solução judiciária por órgãos judicantes internacionais (aos quais se reconhece a competência ex-officio e prévia para os litígios a eles submetidos pelos Estados ou por particulares). Quanto às soluções pacíficas elaboradas a partir dos organismos internacionais, sua formalidade e/ou força normativa e eficaz dependerão das situaçōes dos tratados fundaçōes que os instituíram, ou dos tratados de adesão aos mesmos, conforme se verá a seguir; também, dependerão, "ratione ma-

(6) Apud Direito Internacional Público, Rio de Janeiro, São Paulo, Biblioteca Jurídica Freitas Bastos, 8ª Edição, rev. e aum., 1986, pág. 977 e ss.

(7) Apud: Travaux de l'Association Henri Capitant, Paris, Economica, 1987. 
teriae", dos interesses conflitantes, sendo mais provável que nos organismos de integração econômica, as soluçōes de controvérsias sejam aceitas com mais facilidade que aquelas elaboradas por organismos de natureza política ou diplomática.

Nas últimas três décadas, os conflitos que tiveram sua solução encaminhada através de meios pacíficos na América Latina, conflitos esses que representaram uma ameaça à paz na região, ou que punham em perigo a convivência harmônica das relaçōes comerciais entre os Estados da regiăo, 1 oram os seguintes: a) a situação, ainda não resolvida, na América Central; b) a questão do endividamento externo dos países da região, em vias de equacionamento no que respeita a uma solução g obal e concertada; c) a proscrição de armas nucleares na América Latina; d) a proteção dos direitos humanos; e) o conflito das Malvinas; e f) as formas de integração econômica da regiâo, com a modernização das estruturas existentes (transformação da ALALC na ALADI), ou a criação de órgãos específicos de soluções pacíficas de litígios de natureza econômica (instituição da Corte de Justiça do Acordo de Cartagena, em 28 de maio de 1979) e g) a Questão da Região do Canal de Beagle, que foi submetida à mediação de Sua Santidade o Papa João Paulo II, em decorrência do acordo de submissão assinado entre Argentina e Chile, em Montevidéu, em 8 de janeiro de 1979.

Na América Central, há uma situação de violação da paz na região, representada pela presença de guerrilheiros opositores ao Governo instalado na Nicarágua, que têm agido a partir de ações levadas avante, seja no território da própria Nicarágua, seja a partir de territórios dos Estados vizinhos, com o apoio aberto dos EUA (que foi mesmo trazido às barras da Corte Internacional de Justiça, no episódio da colocação de minas explosivas no litoral da Nicarágua). A partir de 1983, formou-se o Grupo de Contadora entre os seguintes países; que passaram, desde então, a oferecer sua mediação entre a Nicarágua e EUA: Colômbia, México, Panamá e Venezuela) aos quais se juntariam, posteriormente, Argentina, Brasil, Peru e Uruguai, formando o denominado Grupo de Apoio. Em 15 de fevereiro de 1987, num comunicado assinado em San José pelos Presidentes da Costa Rica, El Salvador, Guatemala e Honduras, esses países se aproximam das soluçōes elaboradas pelo Grupo de Contadora e pelo Grupo de Apoio, no sentido de reuniōes formais e conjuntas entre as partes em litígios e as partes mediadoras, em data posterior, em Esquipulas, na Guatemala. Note-se que a proposta de paz na América Central apresentada pela Costa Rica, foi aprovada pelo Senado dos EUA por uma resolução (de 97 a 1 votos) de 12 de março de $1987^{(8)}$.

No que respeita à questão do endividamento externo da América Latina, frente aos credores norte-americanos, europeus-ocidentais e japoneses (bancos

(8) In 26 I.L.M. 573 e as reações de Nicarágua à proposta da Costa Rica, apud 26 I.L.M. 580 (1987). 
e instituições financeiras privados) e frente às instituições creditícias internacionais, (o BIRD e o BID), há poderosas razóes que militam contra uma ação conjunta dos países da região, na elaboração de uma estratégia de renegociação dos débitos, de forma coordenada, harmônica e satisfatória a seus interesses particulares: as estruturas das dívidas são diversas em relação a cada país da América Latina; inexiste um foro de coordenação das políticas exteriores no que respeita à mencionada renegociação conjunta; inexistem formas de relacionamento conjunto da América Latina com as Comunidades Econômicas Européias (a exemplo dos acordos de Lomé entre as antigas colônias africanas e as ex-metrópoles européias), e enfim, inexiste uma real coordenação de políticas econômicas nacionais no que respeita às relaçōes econômicas internacionais, representando os acordos bilaterais CEE/países individuais da América Latina, antes um empecilho à mencionada coordenação de políticas de países da região. É significativo que somente após a admissão da Espanha e Portugal nas Comunidades Européias em 1985, tenha o Parlamento Europeu passado a Resolução (doc. A2-194/86) "sobre as relações econômicas entre a Comunidade Européia e a América Latina (J.O.C.E. № C46/102 de 23 de fevereiro de 1987).

De seu lado, os Ministros das Relaçōes Exteriores e os responsáveis pelas Finanças da Argentina, Bolívia, Brasil, Chile, Colômbia, Equador, México, Peru, República Dominicana, Uruguai e Venezuela, que a imprensa tem denominado Grupo de Cartagena, assinaram um Comunicado Conjunto sobre a Dívida Externa e Desenvolvimento Econômico, em 22 de junho de 1984, em Cartagena de Índia (texto apud 23 I.L.M. 1169 [1984]), com as reaçōes do denominado "Clube de Londres": Canadá, Comunidades Européias, França, R.F. da Alemanha, Itália, Japāo, Reino Unido e EUA, ("Summit Communiqué Text stresses Debtor's Need for Greater Assistance”, no mesmo I.L.M., página 1179). Para os efeitos do presente estudo, importa transcrever: uma das declaraçōes

( $\S 10$. The Ministers reiterated the fact that each country was responsible for its own external debt negotiations. At the same time, they warned that recent experience demonstrated that the foreign debt problem affecting developing countries could not be solved just by talks with banks, the isolated action of multilateral lending organisations or the simple working of market mechanisms. Therefore, general policy guidelines on the restructuring and refinancing of debts had to be defined and accepted so that they might be used as a frame of reference for individual country negotiations. Their implementation had to be adapted to each country's specific circunstances given the wide variety of external debt situations and the different types of measures required to reestablish conditions for growth in each particular economy) 
( $\$ 19$. To carry out the guideline and proposals set forth in this consensus, and contribute to the dialogue with creditor countries, permanently examine the international economic situation and assess the implementation of the proposed initiatives, the Ministers of Foreign Affairs and those responsible for the area of finance decided to institute a mechanisms for regional consultation and follow up. Other countries in the region may participate in this process. $\S 20$. The Ministers agreed that this mechanism for consultation and follow up would be used to: I. facilitate the exchange of information and experiences at the regional leval, as I lell as providing support for technical assistance in relation to debt, financing and similar questions; II. promote contacts with other developing countries outside the region; III. foster a dialogue I/ith the Governments of creditors countries, and using the adequate procedures with international financial organizations and international banks).

Comparados com os procedimentos das décadas anteriores, e com o formalismo exagerado dos esquemas existentes ao nível do sistema interamericano, é notável a tentativa de buscar entendimentos, através da fixação de normas mínimas, dentro de um quadro geral referencial normativo, a partir do qual normas mais específicas e com normatividade específica serão elaboradas ao nível internacional e internamente coordenadas com os parceiros. É a técnica da plena utilização de normas programáticas (muito mais atuantes que os tradicionais "gentlemen's agreements"), que são um dos instrumentais mais adequados na formulação e condução de políticas econômicas, em particular, a nível internacional (a exemplo das diretivas amplamente utilizadas nas Comunidades Econômicas Européias).

A questão do desarmamento, que até o final da Segunda Guerra Mundial e meados de 1960, era tratada em termos de armamentos convencionais, a partir de então, com o fenômeno da escalada nuclear (impossibilidade de estabelecerse um limite entre o armamento clássico e o armamento nuclear, por parte dos Estados detentores de armas nucleares, o que implica na impossibilidade de distinguir-se guerra clássica e guerra nuclear) tem sido tratada em termos de armamento nuclear, tanto nos foros da ONU, quanto em negociaçōes bilaterais EUA-URSS e multilaterais em Genebra, Helsinky e Viena. São tais razōes porque as questōes do desarmamento clássico (redução de exércitos, delimitação de áreas de estacionamento, limitaçōes a ações individuais dos Estados...) têm sido englobadas nas discussões sobre desarmamento nuclear.

Neste particular, a América Latina deu sua contribuição pioneira no Século XX, ao instituir uma área do globo terrestre totalmente livre de armamentos nucleares, e que seria seguida, em época recente, com a adoção, em Raratonga, nas Ilhas Cook, em 6 de agosto de 1985, do Tratado da Zona Livre Nu- 
clear do Pacífico Sul, ("The South Pacific Nuclear Free Zone Treaty", conforme 24 I.L.M. 1440-1985). Trata-se da assinatura do Tratado para a Proscrição de Armas Nucleares na América Latina, assinado na cidade do México, em 14 de fevereiro de 1967, brevitatis causa, que denominaremos Tratado de Tlatelolco (nome do bairro da Capital do México, onde se situa sua Chancelaria, local da firma daquele instrumento internacional).

Também denominado Tratado do México, não resta dúvida que sua elaboração se deveu aos esforços do Embaixador Alfonso Garcia Robles, então Ministro das Relações Exteriores do México, que, somente por tais méritos, além de outros pessoais, mereceu o Prêmio Nobel da Paz de 1982; representa ele uma importante medida colateral ("collateral measure") na expressāo do Prof. Eric Stein ${ }^{(9)}$ no sentido de freiar a corrida armamentista e a proliferação de armas nucleares no mundo. Na verdade, segundo o Prof. Eric Stein, o Tratado de Tlatelolco é uma medida colateral, pois, juntamente com o Tratado da Antártica (Washington, em 1ำ de dezembro de 1959), o Tratado sobre Princípios Reguladores das Atividades dos Estados na Exploração e Uso do Espaço Cósmico, inclusive a Lua e Demais Corpos Celestes (AG da ONU em 19 de dezembro de 1966) e o Tratado de Colocação de Armas Nucleares e outras Armas de Destruição Maciça nos Leitos Marítimos e nos Fundos Oceânicos e no Seu Subsolo (aberto à assinatura na AG da ONU desde outono de 1970), ao lado do Tratado de Moscou de 5 de agosto de 1963 (Proscrição de Experiências com Armas Nucleares na Atmosfera, no Espaço Cósmico e sob a Água) o estabelecimento do "Telefone Vermelho" entre a Casa Branca e o Kremlin (Memorando de Entendimento de 20/06/1963, para diminuir a "síndrome do ataque de surpresa") e a criação pela ONU da Al lência Internacional de Energia Atômica, a AIEA, em Viena em 1957, representam esforços de diminuir a corrida armamentista nuclear.

No que respeita ao Tratado de Tlatelolco, é a tentativa de tornar uma extensa regiảo do universo, livre dos armamentos nucleares. Para tanto, no seu texto principal, estabelece proibiçōes aos Estados signatários da América Latina, no sentido de refrearem-se de colocar, fabricar, transportar, deixar estocar, adquirir... qualquer arma nuclear, definida esta como "qualquer artefato que seja susceptível de liberar energia nuclear de forma não controlada e que tenha um conjunto de características próprias para o seu emprego com fins bélicos" (excluindo-se "o instrumento que possa ser utilizado para o transporte ou a propulsão do artefato... se é separável do artefato e não parte indivisível do mesmo", art. 5o $\S \S 10$ e $2^{\circ}$ do Tratado de Tlatelolco).

Reconhecendo, implicitamente, que qualquer medida colateral e unilateralmente proposta por um grupo de países de uma parte do mundo, no caso o

(9) Apud "Impact of New Weapons Technology in International Law: Select Aspects" in Recueil des Cours da Academia de Dirsito Internacional da Haia, tomo 133, 1971, vol. II, pág. 250 e ss. 
grupo dos países da América Latina, não teria qualquer efeito, se os Estados possuidores de armas nucleares, ou ainda, se os Estados extracontinentais ou continentais que tenham "de jure" ou "de facto" responsabilidade sobre territórios situados na área de aplicação do Tratado, não reconhecessem as medidas auto-impostas, o Tratado de Tlatelolco condicionou o início de vigência de seu texto à assinatura e vigência do Protocolo I (Estados extracontinentais ou continentais com responsabilidade sobre territórios na América Latina) e do Protocolo II (Estados que possuam armas nucleares); sendo assim, somente após a aplicação indireta do Tratado de Tlatelolco à Holanda, Reino Unido, EUA e França (Protocolo I) e aos EUA, URSS, Reino Unido, França e R.P. da China, estará o mesmo em pleno vigor (art. 28 e $\S$ ).

No que respeita ao presente estudo, o Tratado de Tlatelolco estabelecu uma Organização para a Proscrição das Armas Nucleares na América Latina, OPANAL, que, em coordenação com a Agência Internacional de Energia Atômica, AIEA, deverá verificar, através de inspeçōes e controles, a aplicação do Tratado, no território dos países latino-americanos signatários do mesmo. Vêse, assim, que é fundado um organismo internacional, com seus funcionários próprios, anacionais e imunes, com personalidade de Direito Internacional Público própria, enquanto órgãos de soluções de controvérsias e de aplicação das normas do Tratado de Tlatelolco. (Veja-se além, o papel moderno das organizaçōes internacionais na solução pacífica de controvérsias, cujas considerações cabem î | totum à análise do papel da OPANAL).

Na verdade, a criação da OPANAL, como meio de solução pacífica de litígios, é uma das características dominantes dos últimos tempos no Direito Internacional Público, conforme será analisado a seguir, no próximo ítem. Com efeito, a instituição de organismos internacionais, às quais as partes instituidoras conferem jurisdição graciosa e contenciosa sobre determinados assuntos controvertidos, pode ter uma gradação que vai desde órgãos de coordenação política e administrativa, até o grau mais complexo e elevado da criação de tribunais com jurisdiçāo automática e prévia sobre os assuntos de sua alçada (Veja-se além).

No caso da proteção dos direitos humanos na América Latina, não se chegou até o ponto em que a Europa Ocidental atingiu, com a criação da Corte Européia dos Direitos Humanos, com sede em Estrasburgo e competência para conhecer de reclamações de indivíduos contra Estados. A Convenção Americana sobre Direitos Humanos, aprovada na Conferência de San José da Costa Rica em 22 de novembro de 1/ 169, instituía uma Comissão Interamericana de Direito Humano e uma Corte Interamericana de Direitos Humanos, composta de seus juízes nacionais dos Estados signatários, cuja competência é conhecer dos litígios a ela submetidos tão somente pelos Estados-Parte e a Comissão, após o esgotamento dos processos previstos perante esta (art. $61 \S \S 1^{\circ}$ e $2^{\circ}$ ). Sua jurisdi- 
ção não é automática nem obrigatória, ficando tais efeitos condicionados à aceitação dos Estados-Partes da mesma, no momento da ratificação ou adesão da Convenção de San José, ou a qualquer momento (art. $62 \S 1^{\circ}$ ), o que anula, em parte, o dever de dizer o direito da referida Corte, à revelia dos Estados!

Contudo, foi no campo da integração econômica regional que se viu aparecer uma corte judiciária, ao lado de um organismo diplomático permanente: a criação da Corte de Justiça do Acordo de Cartagena ("tout court" Corte de Justiça do Pacto Andino) pelo Tratado assinado entre Bolívia, Colômbia, Equador, Peru e Venezuela, em 28 de maio de 1979, em Cartagena, Colômbia (em vigor a partir de 3 de maio de 1983), com seu Estatuto criado por decisão no 184 da Comissão do Pacto Andino de 9 de agosto de 1983, com sede em Quito, Equador e composto por cinco juízes indicados pelos Estados partes do Pacto Andino ${ }^{(10)}$.

No que se refere à utilização dos meios pacíficos para solução de controvérsias entre Estados da América Latina, duas crises podem provar: a) que a adequada utilização da mediação pode prevenir um conflito bélico entre Parte em litígio (a Questão do Canal de Beagle entre Argentina e Chile) e b) que os instrumentos do sistema interamericano de solução de litígios necessitam um "aggiornamento" aos tempos atuais, a fim de tornar-se operantes e impedir a interferência de Estados extracontinentais nos assuntos situados na América Latina (a Crise das Malvinas).

Coerentes com a tradição secular de resolver os litígios relativos a fronteiras entre os Estados por meios pacíficos, presentes na história da América Latina, Argentina e Chile resolveram submeter à mediação de Sua Santidade o Papa Joāo Paulo II, a disputa relativa aos limites marítimos no extremo sul da América do Sul, no Canal de Beagle. Através de um tratado assinado em Montevidéu em 8 de janeiro de $1979^{(11)}$ os Plenipotenciários da Argentina e do Chile conferiram poderes à Sua Santidade para mediar a disputa, na aplicação "dos requisitos de justiça, eqüidade e prudência, como uma base segura para a coexistência fraterna" de ambos os povos (verbatim).

Já no conflito que opôs a Argentina à Grä-Bretanha, conflito bélico naval, onde numerosas vidas foram perdidas, a propósito da soberania sobre as ilhas Malvinas (que os britânicos denominam Falklands), nem se viu qualquer atuação conjunta dos Países latino-americanos contra a agressão extracontinental (e portanto, o Tratado Interamericano de Assistência Recíproca, TIAR, de 1947 permaneceu letra morta), nem as tentativas de mediação surtiram qualquer

(10) Apud 18 I.L.M. 1203 (1979) e 23 I.L.M. 422 (1984).

(11) Texto apud 18 I.L.M. 1 (1979). 
efeito. A guerra se desenvolveu com sua crueza, tendo a Grã-Bretanha permanecido na posse das llhas Malvinas, sem que o justo título sobre a soberania na região tenha sido esclarecido e fixado pelo Direito Internacional a seu favor.

\section{Solução Pacífica de Controvérsias: Impacto das Organizações Internacionais}

O título desta seção do presente trabalho, propositalmente, repete o mesmo de um trabalho do Prof. Dr. Vicente Marotta Rangel, Prof. Catedrático de Direito Internacional Público da Faculdade de Direito da Universidade de São Paulo, não só por querer-se prestar as homenagens devidas, como, em particular, por ser o referido trabalho extremamente importante para o tema, dada sua oportunidade e sua excelência. $\mathrm{O}$ artigo encontra-se publicado in Anuario Jurídico Interamericano, OEA, Washington, 1985.

O postulado de que os Estados Latino-Ámericanos são indóceis ("reacios") à idéia de uma submissão generalizada e plena de competência a órgãos previamente constituídos, pode, com algum temperamento, ser estendida a todos os Estados na atualidade. É o que se ressalta no mencionado artigo do Prof. Marotta Rangel:

"Em decorrência do postulado da igualdade sobera-
na dos Estados, emerge a regra pela qual a subordi-
nação a processos de soluções de controvérsia de-
pende de consentimento das partes na controvérsia.
Daí se segue também a norma pela qual somente
mediante acordo prévio entre as partes é também
que, em princípio, o processo de solução é escolhi-
do. Como aplicação prática do mesmo postulado
tendem os Estados a preferirem os processos políti-
cos aos jurídicos (12)

Apesar de estar uma organização internacional baseada na vontade expressa do Estado de acatar suas decisōes, o que se depreende da assinatura de um tratado-fundação, ou da adesão a uma organização internacional já existente, o fato é que a aceitação automática da jurisdição das mesmas organizaçōes internacionais não é matéria pacífica. O exemplo mais notável é o da aceitação da jurisdição da Corte Internacional de Justiça, que é a reformulação da anterior Corte Permanente de Justiça Internacional.

Empregamos a expressão jurisdição automática para significar que o órgão judicante tem sua competência e jurisdiçāo fixadas por lei, são elas inafastáveis pelas partes, uma vez que fixadas pelo legislador superior às partes em

(12) Vicente Marotta Rangel, op. cit., pág. 21. 
litígio e em época anterior ao surgimento do litígio; a jurisdição automática é sempre uma força em ação, independente da vontade das partes e, quando em estado latente, guarda os requisitos de vir a ser acionada, pelos motivos elencados em lei, igualmente independentes do querer das partes ou de uma das partes isoladamente. A jurisdição automática repele: a) o conceito de atividade "ad hoc" pois ela existe antes do litígio e se aplica "ratione personae" a todos os indivíduos submetidos a ela; b) o conceito de vontade concertada entre as partes, para determinar sua incidência nos assuntos trazidos a seu julgamento (mesmo que haja concerto entre as partes num tribunal nacional, a intervenção de terceiros pode transmutar o pedido inicial; c) a possibilidade de, por um acordo entre os litigantes, o julgador limitar seus poderes de dizer o direito, ou ainda de aplicar soluçōes não previstas em lei (o caso do julgamento fora das normas de direito, por eqüidade, comuns na arbitragem); d) a mudança da competência do julgador, no curso da lide, pela vontade das partes. Na verdade, na jurisdição automática, a competência e jurisdição do julgador advém de uma norma que as partes não podem modificar, desde o momento em que se submetem a ela, e, portanto, se diz que é uma jurisdição anterior ao litígio.

No outro extremo conceitual, existe o que denominamos jurisdição construída pelas partes, na qual os julgadores retiram seus poderes de um pacto entre os litigantes. Ela inexiste como força atual ou potencial de maneira prévia a uma controvérsia qualquer indefinida: ou ela é criada na emergência de um conflito (por um ato de criação do órgão judicante ou de aceitação de um órgão pré-existente, até então sem jurisdição sobre as partes) ou ela é posta em ação, prevista que estava para um litígio eventual e que no momento ocorreu (constituição do tribunal por força de uma cláusula, que tinha efeitos futuros, a cláusula compromissória, também dita arbitral, com a ocorrência dos pressupostos para sua entrada em ação). Na jurisdição construída pelas partes são totais os efeitos das vontades dos litigantes: a) no momento da constituição do órgão julgador, a determinação de seus poderes (determinação dos limites objetivos e subjetivos da "res judicata" arbitral); b) a prevalência da vontade concertada entre as partes, mesmo durante o decorrer do procedimento, pois é ela a fonte dos poderes do julgador; c) a plena liberdade das partes de ordenar o procedimento a ser seguido pelo julgador; d) a possibilidade de julgamento por eqüidade, fora das formas e regras de direito material existentes, por permissivo das partes.

O exemplo mais acabado da jurisdição automática é o da jurisdição dos órgãos judicantes dos Poderes Judiciários dos Estados; o exemplo da jurisdição construída pelas partes é o do árbitro ou árbitros que as partes elegem para dirimir um conflito. A maneira de instituição dos poderes dos primeiros, como já se disse, é a norma pré-existente à controvérsia; na arbitragem, a instituição dos julgadores, seus poderes e seus limites são criadas por um pacto; o compromisso (de criação da arbitragem para aquele momento) o ato de submissão a um organismo pré-existente, em que se reconhece sua competência e jurisdição 
(veja-se o "terms of referee" existente no Regulamento da Comissão de Arbitragem da Câmara de Comércio Internacional de Paris) ou uma cláusula compromissória, também chamada arbitral, contida em um contrato qualquer (e a cláusula é uma disposição de resolver qualquer controvérsia nascida daquele contrato pela via arbitral, portanto, disposição para o futuro, sem que possa haver um litígio presente).

$\mathrm{Na}$ história recente das relações internacionais, o primeiro tipo de jurisdição que surgiu foi a jurisdição construída pelas partes, e de duas maneiras: a) na constituição de tribunais arbitrais "ad hoc", para resolver controvérsias presentes às partes (vide a utilização generalizada da arbitragem para solucionar litígios entre os Estados, nos Séculos anteriores e, no corrente, na América do Sul, os litígios de fronteiras estatais, em particular, no Brasil, com a atuação do barão do Rio Branco); b) no estabelecimento de um mínimo de regras e uma instituição permanente, a Corte Permanente de Arbitragem, em decorrência das Conferências da Paz da Haia de 1988 e 1907. Guardou a Corte Permanente de Arbitragem da Haia seu caráter de jurisdição construída pelas partes, uma vez que o art. 31 da Convenção da Haia de 1899 dispunha que "as Potências que recorrerem à arbitragem, devem assinar um ato especial (compromisso) no qual, claramente, se determinam o objeto do litígio, assim como a extensão dos poderes dos árbitros. Tal ato implica no comprometimento das Partes a se submeterem de boa fé à sentença arbitral"(13).

Como jurisdição automática, os exemplos mais evidentes nas relações internacionais, são a Corte de Justiça das Comunidades Econômicas Européias e a Corte Européia dos Direitos Humanos, criadas, respectivamente pelo Tratado de Roma de 25/III/1957 (criação da CEE e da EURATOM) e pela Convenção Européia para a Proteção dos Direitos Humanos e Liberdades Fundamentais, assinada, igualmente em Roma, a 4/XI/1950. Assinado o tratado-fundaçāo da CEE (ou a esta admitido, via adesão àquele), assinada a Convenção dos Direitos Humanos de 1957 (ou feita a adesão à mesma), os Estados reconhecem pleno jure as jurisdições dos respectivos tribunais, não sendo necessária a assinatura posterior de qualquer outro ato de submissão aos poderes dos mesmos.

A Corte Permanente de Justiça Internacional, antecessora da atual Corte Internacional de Justiça, de igual forma como esta, não chegou a se constituir em um órgão judicante com uma jurisdição automática plena. $\mathrm{Na}$ verdade, por força do art. 36 e $\S \S$ do Estatuto da Corte Internacional de Justiça, institui-se a denominada cláusula facultativa de jurisdição obrigatória: facultativa porque os Estados podem subscrever atos formais em que reconheçam a jurisdição obrigatória da Corte Internacional de Justiça. Mas, mesmo tendo reconhecido a jurisdição obrigatória da CIJ (seja no ato de a ela serem admitidos, seja em ato

(13) Guido F.S. Soares, Órgãos das Soluções Extrajudiciárias de Litígios, São Paulo, Revista dos. Tribunais, 1985 , pág. 50 e ss. 
posterior), os Estado podem a qualquer momento retirar o seu consentimento na jurisdição automática da mesma; por outro lato, conforme se tem observado, em que pese os termos do Estatuto, no referente à jurisdição da CIJ, os Estados, que submetem uma questão ao julgamento da mesma, na maioria das vezes, firmam um compromisso e nele estabelecem os limites do poder dos julgadores. Pode-se, pois, concluir que a Corte Internacional de Justiça é hoje uma solução a meio caminho entre a adoção da jurisdição construída pelas partes e a jurisdição automática.

No mencionado artigo, o Prof. V. Marotta Rangel admite que

No âmbito de organizações internacionais sucede, pois, cada vez com maior freqüência, que mais de um órgão leve a cabo, em relação com determinado conflito, atividades dirigidas a solucioná-lo. A difusão dessa prática e a tendência à politização das relações internacionais, o que é uma característica dos tempos contemporâneos, atuam no sentido de favorecer a viabilidade de procedimentos pacíficos diferentes ao judicial, inclusive nos casos em que este último seria utilizável. E, tal sentido se orienta particularmente a prática das organizações internacionais, tanto as de caráter político, como as de cunho não político. (Id, p. 23)

O capítulo dos meios pacíficos de soluçōes de conflitos tem sido enriquecido com o nascimento e proliferação das organizações internacionais, sobretudo aquelas de integração econômica. Por responderem estas a uma necessidade econômica premente dos Estados participantes, tendem aquelas soluçōes a ser aceitas pelos participantes, podendo-se dizer que possuem maior hermetismo (no sentido proposto pelo presente estudo) que as soluçōes elaboradas nos organismos de vocação política geral, como a ONU, a OEA ou ainda nos esquemas normativos especialmente elaborados para dirimir controvérsias (a CIJ, o Pacto de Bogotá...).

Já se fez referência à recente criação da Corte de Justiça do Pacto Andino, criado dentro do marco institucional do Acordo de Cartagena, acordo esse que instituiu uma organização de integração econômica do tipo aproximado a um mercado comum (portanto, mais integrativo que as organizaçōes de integração econômica do tipo área de livre comércio).

Merece transcrição, para o exame do caso de dois outros organismos de integração econômica existentes na América Latina, a ALADI (ALALC) e o MCCA, as palavras escritas pelo referido Prof. Vicente Marotta Rangel (Id., p. 38), com abundante citação de outras autoridades: 
Desde 1967, a ALALC contou, observa BARROS CHARLIN, com um sistema de soluçāo de controvérsias que "combina as negociaçōes diplomáticas clássicas com instâncias arbitrais e às quais jamais recorreram as Partes Contratantes, tradicionalmente partidárias dos entendimentos diretos". O tratado constitutivo da ALALC contemplava nos artigos 22 e 23 a possibilidade de controvérsias entre as partes contratantes e se referia aos procedimentos a seguir em tais casos; Resoluçōes das Conferências das Partes Contratantes também instituíram procedimentos específicos para a eventualidade em que a aplicação dessas Resoluções provocasse discrepâncias, "Tambien es cierto - pondera Felipe Paolillo que los órganos comunes de las instituciones de integración aparecen como foros naturales, en donde los Estados Miembros pueden ventilar sus diferencias, provocar un examen público de las mismas, y aún intentar la búsqueda, de manera informal, de una solución. Pero en ningun caso puede hablarse de "mecanismos" o de "sistema de solución de controversias" y mucho menos de "procedimientos jurisdiccionales". Se trata de un conjunto de procedimientos simples, informales y flexibles, no vinculados entre sí, generalmente establecidos y utilizados "ad hoc", y que en la práctica terminaron frecuentemente, por adoptar la forma de negociaciones diplomáticas". É o que também assevera estudo, publicado em 1971, "de los procedimientos de derecho utilizados para la solución de conflictos en la ALALC", no qual, entre outras conclusōes gerais, se diz que "solo en un reducido número de controversias, los puntos conflictivos, fueron objeto de análisis jurídiso muy profundos". O tratado instituido da ALADI, de 12 de agosto de 1980, não trouxe inovaçōes a respeito ${ }^{(14)}$.

(14) Vicente Marotta Rangel, op. cit., p. 38; as citações de Barros Charlin são de "Analisis Comparativo de los Tratados de Montevideo 1960 y 1980" in El Derecho de la Integración en América Latina, 1979. 1982, INTAL-BID, 1983, vol. I, p. 234 nota 14 in fine; e Felipe Paolillo "El Tribunal de Justicia del Acuerdo de Cartagena”, in Perspectivas, vol. 2, p. 107 e F. Paolillo e Carlos Ons Idart, "Estudios de los Procedimientos de Hecho Utilizados para la Solución de Conflictos en la ALAC" in Derecho de la Integración, INTAL, no 9, outub. de 1971, pp. 19 a 74, conforme notas no artigo do Prof. V Marotta Rangel, "Solução Pacífica de Controvérsias e o Impacto das Organizações Internacionais", já mencionado. 
$\mathrm{Na}$ verdade, nos fenômenos de integração econômica, o fato de os Estados juntarem esforços para, em comum, realizarem uma tarefa que lhes é impossível realizar sozinhos, ou que é dificultada pela ação concorrencial de outros Estados vizinhos, representa um meio de solução pacífica de conflito. Dois exemplos merecem destaque, na América do Sul: a) a criação de empresas estatais binacionais, de natureza empresarial (a ITAIPU-BINACIONAL e CORPUS); e b) a instituição de organismos comunitários de gestão de recursos internacionais: no Tratado da Bacia do Prata assinado em Brasília a 23 de abril de 1969 e no Tratado de Cooperação Amazônica, assinado na mesma Capital, em 3 de julho de 1978, sendo que este último tipo, embora não seja um esquema de integração econômica "stricto sensu", pelas motivações econômicas de explotação comum dos recursos considerados, pode assim ser tido.

Por outro lado, igualmente, merece destaque a emergência de outros órgãos dos Estados na condução da diplomacia, que se alarga para compreender não só os Chefes dos Poderes Executivos, mas țambém os órgãos da Administração Indireta (ou Descentralizada, como é o caso da ELETROBRÁS e da ANDE na BINACIONAL ITAIPU) e ainda os Poderes Legislativos dos Estados (a institucionalização do Parlamento Latino-Americano, em Lima, em 16 de novembro de 1987).

O Tratado entre a República Federativa do Brasil e a República do Paraguai para o "Aproveitamento Hidrelétrico dos Recursos Hídricos do Rio Paraná, Pertencentes em Condomínio aos Dois Países, desde e inclusive o Salto Grande de Sete Quedas ou Salto de Guaíra até a Foz do Rio Iguaçu", assinado em Brasília, em 26 de abril de 1973, de maneira satisfatória e inteligente solucionou uma série de questōes entre ambos os países. Foi o espírito contemporâneo que preside o moderno Direito Internacional Público que animou seu nascimento: a noção de que as normas internacionais são antes normas de construção de padrōes harmoniosos de cooperação internacional do que esquemas probitivos de condutas indesejáveis, (dando razão aos doutrinadores que vêm na norma de Direito Internacional um sistema mais de atuações do que um sistema de proibições, o Direito da Cooperação, contra o Direito Internacional Clássico).

Firmado entre Estados, Brasil e Paraguai, o Tratado de Brasilia deixa intocados os limites ribeirinhos entre ambos os países e cria uma empresa binacional, com uma dupla sede, em Brasília e em Assunção, com uma presidência de duas cabeças (brasileira e paraguaia) e a diretoria dividida equanimemente entre as nacionalidades dos dois países, a empresa ITAIPU, com personalidade jurídica própria, e a finalidade de realizar o aproveitamento hidrelétrico dos recursos hídricos abrangidos pelo tratado. Constituída com a igual participação acionária da ELETROBRÁS, sociedade de economia mista de Direito brasileiro e da ANDE, autarquia de Direito paraguaio, terá, enquanto empresa de natureza comercial, as funçōes de administrar o empreendimento nascido com o trata- 
do e realizar operaçōes comerciais com terceiros (preferentemente, de nacionalidade brasileira ou paraguaia, na verdade, empresas controladas pelo Estado, uma vez que dedicadas à produção de energia elétrica, em ambos os países, atividades, por lei, monopolizadas pelo Estado).

Sem qualquer imunidade de jurisdição ou de execução, pois empresa de natureza comercial, a ITAIPU-BINACIONAL está sujeita às regras dos direitos privados, tanto nas relações comerciais, quanto nas relaçōes trabalhistas em que entrar como parceiro ou contratador ${ }^{(15)}$. As divergências surgidas, no que respeita à aplicação e execução do tratado serāo resolvidas pelo Conselho da ITAIPU, mas, as divergências entre os Estados (art. XXII), serão resolvidas pelos meios diplomáticos usuais, "o que nāo retardará ou interromperá a construção elou a operação do aproveitamento hidrelétrico e de suas obras e instalações auxiliares".

Em idêntico espírito que animou a instituição da ITAIPU-BINACIONAL, em 3 de dezembro de 1974, os Chanceleres da Argentina e do Paraguai, em 3 de dezembro de 1973, assinaram em Assunção, o Tratado de Yaciretá, para o aproveitamento hidrelétrico, a melhoria das condiçōes de navegabilidade do Rio Paraná na altura da Ilha de Yaciretá e, eventualmente, a atenuação dos efeitos depredadores das inundaçōes produzidas por enchentes extraordinárias. É criada, igualmente, uma entidade binacional a YACIRETÁ, nos mesmos moldes que a ITAIPU-BINACIONAL.

O que é mais notável no assunto, foi a assinatura de um Acordo Tripartite assinado na cidade de Presidente Stroessner, no Paraguai, entre os Ministros das Relações Exteriores desse país, da Argentina e do Brasil, com vistas a uma coordenação dos trabalhos relativos ao regime comum do Rio Paraná e à compatibilização entre as monumentais obras de engenharia dos complexos ITAIPU e YACIRETÁ.

Importa transcrever as palavras do Prof. Dr. Jerónimo Irala Burgos, Decano da Faculdade de Ciências Jurídicas e Diplomáticas da Universidade Católica de Assunção, no seu artigo "Los Acuerdos de Itaipu, Yacireta y Corpus sobre la Explotación de los Recursos Hidroelétricos del Rio Paraná: una Nueva Forma de Cooperación Internacional en la Cuenca del Prata, entre Paraguay, Brasil y Argentina:

Los conflictos y tensiones que enfrentaban a países del área en pleitos cuyos orígenes se remontam al coloniaje, hoy están encontrando un adecuado marco jurídico y una rica canalización económica capa-

(15) Veja-se: Guido F.S. Soares Das Imunidades de Jurisdição e de Execução, Sāo Paulo, Ed. Forense, 1983. 
ces de convertirlos en motivos de cooperación e inclusive de integración. Así como Alemania y Francia superaron una rivalidad secular, marcada inclusive con sangrientas guerras, por medio de un modelo de integración tan audaz como fué en su momento, el de la Comunidad Económica del Carbón 11 del Acero, Argentina, Brasil y Paraguay están eliminando obstáculos que se interponían en sus relaciones internacionales y llegando a acuerdos que, consolidados en la región, se proyectarán sin duda a áreas cada vez más extensas y contribuirán a hacer que América Latina vaya conquistando una presencia y una capacidad negociadora de creciente importancia en la política mundial. (Asunción, Noviembre de 1979).

No que se refere às normas relativas aos espaços de interesse comum na América do Sul, e também dentro do espírito que presidiu a formação de ITAIPU-BINACIONAL e da empresa Argentina-Paraguaia, merecem destaques dois Tratados assinados em Brasília: o Tratado da Bacia do Prata de 23 de abril de 1969 e o Tratado de Cooperação Amazônica de 3 de julho de 1978. São ambos tratados fechados, não susceptíveis de receber adesōes e têm em comum o fato de não prever soluções pacíficas de controvérsias por órgãos estranhos a eles (nem cláusulas arbitrais, nem qualquer outro recurso à arbitragem ou soluçāo judiciária em caso de desavença na interpretação dos textos). Na verdade, ambos criam órgãos de implementação dos tratados, que representam a função de executores das medidas propostas e de foros de resolução de controvérsias.

\section{Artigo II}

Os Ministros das Relações Exteriores dos Países da Bacia do Prata reunirse-ão uma vez por ano, em data que será sugerida pelo Comitê Intergovernamental Coordenador, a fim de traçar diretrizes básicas da política comum para a consecução dos propósitos estabelecidos neste Tratado; apreciar e avaliar os resultados obtidos; celebrar consultas sobre a ação de seus respectivos Governos no âmbito do Desenvolvimento multinacional integrado da Bacia; dirigir a ação do Comitê Intergovernamental Coordenador e, em geral, adotar as providências necessárias ao cumprimento do presente Tratado através das realizaçōes concretas por ele requeridas.

Parágrafo Primeiro. Os Ministros das Relações Exteriores poderão reunirse em sessão extraordinária, mediante convocação efetuada pelo Comitê Intergovernamental Coordenador por solicitação de pelo menos três das Partes Contratantes.

Parágrafo Segundo. Se excepcionalmente o Ministro das Relações Exteriores de uma das Partes Contratantes não puder comparecer a uma reunião, ordinária ou extraordinária, far-se-á representar por um Delegado Especial. 
Parágrafo Terceiro. As decisões tomadas em reuniões efetuadas em conformidade com este artigo requererão sempre o voto unânime dos cinco países.

\section{Artigo III}

Para os fins do presente Tratado, o comitê Intergovernamental Coordenador é reconhecido como o órgão permanente da Bacia encarregado de promover, coordenar e acompanhar o andamento das ações multinacionais, que tenham por objeto o desenvolvimento integrado da Bacia do Prata, e da assistência técnica e financeira que promova com o apoio dos organismos internacionais que estime convenientes, bem como de executar as decisōes que adotem os Ministros das Relaçōes Exteriores.

Parágrafo Primeiro. O Comitê Intergovernamental Coordenador se regerá pelo Estatuto aprovado na segunda Reunião de Chanceleres dos Países da Bacia do Prata, celebrada em Santa Cruz de la Sierra, Bolívia, de 18 a 20 de maio de 1968.

Parágrafo Segundo Em reunião extraordinária, para tal fim especialmente convocada, poderão os Ministros das Relações Exteriores, sempre pelo voto unânime dos cinco países, reformar o Estatuto do Comitê Intergovernamental Coordenador.

\section{Artigo IV}

Sem prejuízo das disposiçōes internas de cada país, serão órgãos de cooperação e assessoramento dos Governos as Comissões ou Secretarias nacionais, constituídas de conformidade com a Declaração Conjunta de Buenos Aires. As Comissões ou Secretarias poderão estabelecer contatos bilaterais, obedecendo sempre aos critérios e normas dos países interessados e disso mantendo devidamente informado, quando for o caso, o Comitê Intergovernamental Coordenador.

O Tratado de Cooperação Amazônica assinado em Brasília a 3 de julho de 1978, entre as Repúblicas da Bolívia, do Brasil, da Colômbia, do Equador, da Guiana, do Peru, do Suriname e da Venezuela, é um texto complexo, que versa desde questōes relativas à preservação do meio ambiente, até a liberdade de navegação do Rio Amazonas, em direção ao Atlântico. Seu art. XXVI expressamente declara ser sua duraçāo ilimitada e não estar aberto a adesōes. Para o tema em estudo importa transcrever o seguinte:

\section{Artigo XX}

Sem prejuízo de que posteriormente se estabeleça a periodicidade mais adequada, os Ministros das Relaçōes Exteriores das Partes Contratantes realizarāo reuniōes cada vez que o julguem conveniente ou oportuno, a fim de fixar as diretrizes básicas da política comum, apreciar e avaliar o andamento geral do processo de cooperação amazônica e adotar as decisões tendentes à realização dos fins propostos neste instrumento. 
Parágrafo Primeiro. Celebrar-se-ão reuniões dos Ministros das Relaçōes Exteriores por iniciativa de qualquer das Partes Contratantes sempre que conte com o apoio de pelo menos outros quatro Estados Membros.

Parágrafo Segundo. A primeira reunião de Ministros das Relações Exteriores celebrar-se-á dentro de dois anos seguintes à data de entrada em vigor do presente Tratado. A sede e a data da primeira reunião serão fixadas mediante entendimento entre as Chancelarias das Partes Contratantes.

Parágrafo Terceiro. A designação do país sede das reuniōes obedecerá ao critério de rodízio por ordem alfabética.

\section{Artigo XXI}

Representantes diplomáticos de alto nível das Partes Contratantes reunir-se-ão, anualmente, integrando o Conselho de Cooperação Amazônica, com as seguintes atribuiçōes:

1. Velar pelo cumprimento dos objetivos e finalidades do Tratado.

2. V elar pelo cumprimento das decisões tomadas nas reuniōes de Ministros das Relações Exteriores.

3. Recomendar às Partes a conveniência ou oportunidade de celebrar reuniōes de Ministros das Relações Exteriores e preparar o temário correspondente.

4. Considerar as iniciativas e os projetos que apresentem as Partes e adotar as decisões pertinentes para a realização de estudos e projetos bilaterais ou multilaterais, cuja execução, quando for o caso, estará a cargo das Comissōes Nacionais Permanentes.

5. Avaliar o cumprimento dos projetos de interesse bilaterais ou multilateral.

6. Adotar as normas para o seu funcionamento.

Parágrafo Primeiro. O Conselho poderá celebrar reuniōes extraordinárias por iniciativa de qualquer das Partes Contratantes, com o apoio da maioria das demais.

Parágrafo Segundo. A sede das reuniōes ordinárias obedecerá ao critério de rodízio, por ordem alfabética, entre as Partes Contratantes.

\section{Artigo XXII}

As funções de Secretaria serão exercidas, pro tempore, pela Parte Contratante em cujo território deva celebrar-se a seguinte reuniāo ordinária do Conselho de Cooperação Amazônica.

Parágrafo Único. A Secretaria pro tempore enviará, às Partes, a documentação pertinente. 


\section{Artigo XXIII}

As Partes Contratantes criarão Comissōes Nacionais Permanentes encarregadas da aplicação, em seus respectivos territórios, das disposições deste Tratado, assim como da execução das decisões adotadas pelas reuniões dos Ministros das Relações Exteriores e pelo Conselho de Cooperação Amazônica, sem prejuízo de outras atividades que lhes sejam atribuídas por cada Estado.

\section{Artigo XXIV}

Sempre que necessário, as Partes Contratantes poderão constituir comissões especiais destinadas ao estudo de problemas ou temas específicos relacionados com os fins deste Tratado.

Dos textos transcritos, importa observar a similitude de atribuiçōes entre o Comitê Intergovernamental de Coordenação do Tratado da Bacia do Prata e o Comitê Intergovernamental Coordenador do Tratado de Cooperação Amazônica. Não só órgãos diplomáticos de assegurar a vigência dos tratados, mas igualmente órgãos executivos de coordenação de políticas governamentais e de solução pacífica de controvérsias.

Finalmente, digno de nota no capítulo de solução pacífica de controvérsias, foi o Tratado de Institucionalização do Parlamento Latino-Americano, assinado em Lima, em novembro, dia 16 de $1988^{(16)}$ por delegações dos seguintes países: Argentina, Bolívia, Brasil, Colômbia, Costa Rica, Cuba, Equador, El Salvador, Guatemala, Honduras, México, Nicarágua, Panamá, Paraguai, Peru, República Dominicana, Uruguai e Venezuela. Revelando a mais clara tendência das relações internacionais do Século $X X$, da sua democratização, a mencionada institucionalização, a exemplo do que ocorre com os Países da Europa Ocidental integrantes das Comunidades Econômicas Européias (o Parlamento Europeu), tenta tornar os Poderes Legislativos dos Estados copartícipes na formulaçāo e condução dos procedimentos diplomáticos e da política exterior dos Estados.

\section{Um Estudo de Caso: Soluçōes Arbitrais Previstas em Tratados em que o Brasil é Parte}

A arbitragem, como já se mencionou, tem sua base de criaçāo e de limites de atuação, na vontade das partes em litígio: trata-se da instituição de órgão ou órgãos judicantes, pela vontade presente e determinada numa controvérsia presente (o compromisso, ato formal que descreve o litígio e limita os poderes dos árbitros) ou pela vontade generalizada, com efeitos futuros, numa controvérsia que poderá acontecer entre as partes (cláusula compromissória ou arbitral, constante em acordos mais gerais). A grande distinção entre o compromisso e a

(16) Texto in 27 I.L.M. 430 (1988). 
cláusula arbitral é a precisão em que descrevem os efeitos da manifestação da vontade: no compromisso, nomeiam-se os árbitros, descrevem-se suas atribuições, os prazos de decisão e, inclusive, os eventuais efeitos das decisões prolatadas na sentença arbitral; e fundamental no compromisso, a descrição do litígio, seu objeto, o que constituirá nos limites dentro dos quais os árbitros deverão atuar.

Já na cláusula compromissória, inexiste litígio, mesmo que as partes venham a delimitar o objeto de uma eventual controvérsia, não poderão ter o suficiente grau de previsibilidade a ponto de descrever os detalhes de uma controvérsia. $\mathrm{Na}$ verdade, o direito privado comparado dos Estados apontam diferentes efeitos às cláusulas compromissórias nos contratos entre particulares, que podem, com alguma adaptação, ser aplicados aos tratados: a) o efeito de uma promessa (de louvar-se em árbitros, obrigando as partes a construir o tribunal julgador ou a instituir o árbitro único); b) o efeito negativo de afastar outras soluçōes de litígios, notadamente, em algumas legislações, a ida aos poderes judiciários locais. No Direito Internacional, dependendo dos termos em que a cláusula é redigida nos tratados, pode ela representar um meio alternativo de recurso à arbitragem, ou um meio direto, na hipótese de falharem ou não ser possíveis outras soluçōes (como os bons ofícios, a mediação...).

No caso do presente artigo, para ilustrar os tipos de cláusulas compromissórias (ou arbitrais), fez-se um levantamento dos tratados em devida forma assinados pelo Brasil e dentre os mais significativos, arrolaram-se algumas cláusulas que podem ilustrar sua complexidade. Note-se, de início, que semelhantes cláusulas obedeceram a um costume internacional, não refletindo uma posiçăo pré-estabelecida no que respeita uma tipificação das mesmas segundo uma praxe da diplomacia brasileira. Foram os tratados agrupados em três grupos: 1. tratados multilaterais; 2. tratados trilaterais (Brasil, EUA e a AIEA) e 3. tratados bilaterais. $\mathrm{O}$ citado levantamento tentou reunir tratados e convençōes vigentes para além do sistema interamericano, como tem sido a preocupação do presente trabalho.

\section{1 - Tratados Multilaterais ${ }^{(17)}$}

1.1 - Convenção para a Proteção dos Bens Culturais em caso de Conflito Armado, assinada na Haia, em 14 de março de 1954, Decreto $\mathrm{n}$ - 44.851/58 (DOU-24 de novembro de 1958).

(17) A primeira data se refere à assinatura dos acordos. O Decreto é o da promulgação, em geral, acompanhado do texto oficial dos acordos. Elidiram-se as datas de início de vigência na ordem internacional, bem como as datas de aprovação pelo Congresso Nacional Brasileiro. 


\section{Art. XXI - Processo de Conciliação}

1. As Potências protetoras prestarāo seus bons ofícios, sempre que o considerem conveniente no interesse dos bens culturais e, especialmente, se as Partes em conflito não estiverem em acordo quanto à aplicaçāo ou à interpretação das disposiçōes da presente Convenção ou de seu Regulamento.

2. Para esse fim, cada uma das Potências - protetoras, a pedido de uma das Partes ou do Diretor-Geral da Organização ds N̦ações Unidas para a Educação, a Ciência e a Cultura, ou por iniciativa própria, poderá propor às Partes em Conflito uma reunião de seus representantes, e, em particular, das autoridades incumbidas da proteção dos bens culturais, a qual poderá eventualmente ser celebrada em território de um país neutro apropriadamente escolhido. As partes em conflito ficam obrigadas a aceitar as propostas de reunião que lhes forem feitas. As potências protetoras proporão às Partes em conflito, para a sua aprovação, o nome de uma personalidade nacional de um país neutro, ou de uma pessoa indicada pelo Diretor-Geral da Organização das Nações Unidas para a Educação, a Ciência e a Cultura, a qual será convidada a participar dessa reunião na qualidade de presidente.

\section{2 - Convenção sobre Privilégios e Imunidades das Agências Espe- cializadas das Nações Unidas, adotada pela Assembléia Geral da ONU em 21 de novembro de 1947, Decreto no 52.288/63 (DOU-30 de julho de 1963).}

\section{1* Seção}

Cada Agência especializada providenciará modos apropriados de resolver:

a) Disputas resultantes de contratos ou outras disputas de caráter privado nas quais a agência especializada seja parte;

b) Disputas que envolvam qualquer funcionário de uma agência especializada que, por motivo de sua posição oficial, goze de imunidade, se a imunidade não houver sido dispensada, de conformidade com as disposições da 22ª Seção.

\section{2보 Seção}

Todas as divergências resultantes da interpretação ou aplicação da presente Convenção serão submetidas à Corte Internacional de 
Justiça, a não ser que, em qualquer caso, as partes convenham em recorrer a outro modo de solução. Se surgir divergência entre uma das agências especializadas, por um lado, e um membro do outro, pedir-se-á um parecer consultivo sobre qualquer questão legal em causa, de acordo com o artigo 96 da Carta e o artigo 65 do Estatuto da Corte e as disposiçōes aplicáveis dos ajustes concluídos entre as Nações Unidas e a agência especializada interessada. $\mathrm{O}$ parecer emitido pela Corte será aceito como decisório pelas partes.

1.3 - Convenção Única sobre Entorpecentes, assinada em Nova York em 30 de março de 1961, Decreto n- 54.216/64 (DOU-1ํ de setembro de 1964).

\section{Art. 48 - Controvérsias}

1. Se surgir entre duas ou mais Partes uma controvérsia acerca da interpretação ou da aplicação da presente Convenção, as referidas Partes se entenderão com o fim de resolver a controvérsia, seja por negociaçōes, investigação, mediação, conciliação, arbitragem, recurso a organismos regionais, processo judicial, ou outros recursos pacíficos que elas venham a escolher.

2. Qualquer controvérsia que não possa ser resolvida na forma prevista será submetida à Corte Internacional de Justiça.

\section{4 - Acordo sobre Privilégios e Imunidades da Agência Internacio-} nal de Energia Atômica, aprovado pela Junta de Governadores da AIEA, em Viena, a 10 de julho de 1959, Decreto no $59.309 / 66$ (DOU-30 de setembro de 1966).

Art. X - Solução de controvérsias

Seção 33!

A Agência deverá prever processos adequados de solução para:

a) as controvérsias em matéria de contratos e outras controvérsias de direito privado nas quais a Agência for parte;

b) as controvérsias nas quais estiver implicado um funcionário ou um perito da Agência que, em virtude de sua situação oficial, gozar de imunidade se esta imunidade não tiver sido suspensa de acordo com as disposições das Seçōes $21^{\text {a }}$ e $25^{\text {a }}$. 
Seção $34^{\mathrm{a}}$

A menos que, num caso determinado, as partes convenham em recorrer a outro meio de solução, qualquer dúvida resultante da interpretação ou aplicação do presente Acordo será submetida à Corte Internacional de Justiça de acordo com o Estatuto da Corte. Se surgir uma controvérsia entre a Agência e um Estado-Membro e as partes não convirem em outro meio de solução, será pedido um parecer consultivo sobre qualquer questāo legal suscitada, de acordo com o Artigo 96 da Carta das Naçōes Unidas e do Artigo 65 do Estatuto da Corte, assim como as disposiçōes correspondentes do Acordo concluído entre a Organização das Naçōes Unidas e a Agência. O parecer da Corte será aceito pelas partes como decisivo.

1.5 - Convenção de Aviação Civil Internacional, (Criação da OACI) adotada em Chicago em 1944.

\author{
Capítulo XVIII \\ Disputas e falta de Cumprimento \\ Artigo LXXXIV \\ Solução de Disputas
}

Qualquer desacordo entre dois ou mais Estados contratantes sobre a interpretação ou a aplicação desta Convenção e seus anexos que não puder ser resolvido por meio de negociações será, mediante pedido de qualquer dos Estados, envolvido no desacordo decidido pelo Conselho. Nenhum membro do Conselho terá direito a voto na solução pelo Conselho de qualquer disputa na qual seja parte interessada. Qualquer Estado contratante poderá, observado o disposto no Artigo LXXXV, pedir revisão da decisão do Conselho a um tribunal arbitral ad hoc, aceito pelos demais interessados, ou à Corte Permanente de Justiça Internacional. Qualquer Recurso desta ordem será levado ao conhecimento do Conselho dentro do prazo de 60 dias, contados a partir da data do recebimento de notificação da decisão do Conselho.

\title{
Artigo LXXXV \\ Processo Arbitral
}

Se qualquer Estado contratante envolvido em disputa na qual a decisão do Conselho estiver sendo apelada não tiver aceito o Estatuto da Corte Permanente de Justiça Internacional e os Estados contratantes interessados nāo chegarem a um acordo no tocante à 
escolha do tribunal arbitral, cada um dos Estados contratantes, parte na disputa, nomeará um árbitro e estes indicarão um juiz. Se algum Estado contratante envolvido na disputa deixar de nomear um árbitro dentro de um período de três meses, contados a partir da data do apêlo, o Presidente do Conselho escolherá, de uma lista de indivíduos qualificados e disponíveis, mantida pelo Conselho, um árbitro para este Estado. Se, dentro de trinta (30) dias, os árbitros não chegarem a um acordo sobre o juiz, o Presidente do Conselho escolherá um juiz da referida lista. Os árbitros e o juiz constituirão então, conjuntamente, um tribunal arbitral. Qualquer tribunal arbitral constituído nos termos deste ou do precedente artigo adotará seu próprio processo e decidirá por maioria de votos, podendo entretanto o Conselho determinar o processo a ser adotado na hipótese de dar-se um atraso excessivo na sua opinião.

\section{2 - Trilaterais}

Acordo para a Aplicação de Salvaguardas entre o Brasil, os Estados Unidos e a Agência Internacional de Energia Atômica, concluído em Viena, a 10 de março de 1967, Decreto n 63.705/68 (DOU-4 de dezembro de 1968).

\section{Parte VII - Solução de Litígios}

Seção $27^{\mathrm{a}}$

Qualquer controvérsia surgida da interpretação ou aplicação deste Acordo não solucionada por negociação ou por outro meio acordado entre as Partes interessadas, será submetida, a pedido de qualquer Parte, a um tribunal arbitral constituído como segue:

(a) Se a controvérsia envolver apenas duas das Partes deste Acordo, concordando as três Partes em que a terceira não se acha envolvida, as duas Partes interessadas designarão, cada uma, um árbitro, e os dois árbitros assim designados elegerão um terceiro, que será o Presidente. Se, no fim de trinta dias após o pedido de arbitramento, uma das duas Partes não tiver designado um árbitro, qualquer uma das duas poderá solicitar ao Presidente da Corte Internacional de Justiça que designe um árbitro. Adotar-se-á o mesmo procedimento se, dentro de trinta dias após a designação ou nomeação do segundo árbitro, o terceiro não tiver sido eleito; ou 
(b) Se a controvérsia envolver as três Partes neste Acordo, cada parte designará um árbitro e os três árbitros assim designados elegerāo, por decisão unânime, um quarto árbitro, que será o Presidente, e um quinto. Se, dentro de trinta dias após o pedido de arbitramento, qualquer das Partes não tiver designado um árbitro, qualquer delas poderá solicitar ao Presidente da Corte Internacional de Justiça para nomear o número necessário de árbitros. Aplicar-se-á o mesmo procedimento se, dentro de trinta dias após a designação ou nomeação do terceiro dos primeiros três árbitros, o Presidente ou o quinto árbitro não tiverem sido eleitos.

A maioria dos Membros do Tribunal arbitral constituirá quórum, e as decisões serāo tomadas por voto da maioria. $\mathrm{O}$ procedimento arbitral será estabelecido pelo tribunal. As decisōes do tribunal, inclusive todas as normas relativas à sua constituição, procedimento, jurisdição e a divisão entre as Partes das despesas do arbitramento obrigarão todas as Partes. A remuneração dos árbitros será fixada na mesma base daquela relativa aos juízes ad hoc da Corte Internacional de Justiça.

Seçāo 28ª

As decisōes da Junta relativas à implementação deste Acordo, com exceção das relativas apenas à Parte VI, serão imediatamente postas em execução pelas Partes, se assim estiver previsto, até a solução final de qualquer controvérsia ${ }^{(18)}$.

\section{3 - Bilaterais}

\section{1 - Tratados de Paz}

3.1.1 - Acordo entre o Brasil e a Itália para Incentivar as Relações de Colaboração entre os Dois Países e Resolver as Questões Atinentes ao Tratado de Paz, firmado no Rio de Janeiro a 8 de outubro de 1949, Decreto no $28.369 / 50$ (DOU-3 de agosto de 1950).

\section{Artigo X}

Caso surjam entre os dois Governos divergências - o que se espera não aconteça - quanto à interpretação ou aplicação do presente

(18) A Parte VI diz respeito às despesas com a implementação das responsabilidades, que deverão ser arcadas meio a meio pelos signatários, bem como a responsabilidade exclusiva do Brasil, perante terceiros, por risco nuclear e seguros. 
acordo, e que não possam estas ser resolvidas pelas vias diplomáticas normais, ou mediante um árbitro, caso com sua nomeação concordassem os dois Governos as eventuais controvérsias serão deferidas à Corte Internacional de Justiça.

3.1.2 - Tratado de Paz com o Japão, firmado em São Francisco, EUA, a 8 de setembro de 1951, Decreto $n^{\mathbf{0}}$ 30.948/52 (DOU-23 de junho de 1952).

\section{Capítulo VI - Solução de Conflitos \\ Artigo 22}

Se, na opinião de algumas das Partes signatárias do presente Tratado, surgir um conflito quanto à interpretação ou execução do Tratado que não possa ser resolvido por recurso a um Tribunal especial de reclamação ou por outro meio adotado de acordo, a pendência será a requerimento de qualquer das Partes, submetida à decisão da Corte Internacional de Justiça. O Japão e as Potências Aliadas, que não sejam ainda partes do Estatuto da Corte Internacional de Justiça, depositarão, junto ao Escrivão da Corte, na ocasiāo em que ratificarem o presente Tratado, e em conformidade com a resolução, de 15 de outubro de 1946, do Conselho de Segurança das Naçōes Unidas, a declaração geral de que aceitam a jurisdição da Corte de maneira geral e sem necessidade de acordo especial, quanto a todos os conflitos a que se refere este Artigo.

\section{2 - Para evitar dupla-tributação}

3.2.1 - Brasil-Noruega, Convenção para Evitar a Dupla-Tributação e Prevenir Evasão Fiscal em Matéria de Impostos sobre a Renda e o Capital, assinada no Rio de Janeiro a 20 de outubro de 1967, Decreto no 66.110/70 (DOU-28 de janeiro de 1970, pág. 657/661).

\section{Artigo 25 - Procedimento Amigável}

(1) Quando uma residente em um Estado Contratante considerar que as medidas tomadas por um ou por ambos os Estados Contratantes conduzam ou possam conduzir, em relação a ele, a uma tributação contrária às disposições da presente Convenção, poderá independentemente dos recursos previstos pela legislação nacional desses Estados, submeter o seu caso à apreciaçāo da autoridade competente do Estado Contratante onde residir. 
(2) A autoridade competente, se a reclamação se lhe afigurar justificada e não dispuser de meios para lhe dar uma solução satisfatória, esforçar-se a por resolver o caso por meio de um entendimento amigável com a autoridade competente do outro Estado Contratante, a fim de evitar uma tributação em desacordo com esta Convenção.

(3) As autoridades competentes dos Estados Contratantes esforçar-se-ão por resolver, através de acordo amigável, as dificuldades ou as dúvidas a que possa dar lugar a interpretação ou aplicação da Convenção. Podem também conferenciar a fim de evitar a dupla tributação nos casos não previstos na Convenção.

(4) As autoridades competentes dos Estados Contratantes poderão comunicar-se diretamente entre si a fim de buscar um acordo nos termos indicados nos parágrafos anteriores.
3.2.2 - Brasil-Finlândia, Decreto no 73.496/74 (DOU-21 de janei- ro de 1974).
Art. 25 - "ipsis litteris" com o Brasil-Noruega.
3.2.3 - Brasil-França, Decreto no 70.506/72 (DOU-16 de maio de 1972).
Art. 25 - "ipsis litteris" como Brasil-Noruega.

\section{3 - Sobre Transportes Aéreos Regulares}

3.3.1 - Brasil-Espanha firmado no Rio de Janeiro, a 28 de novembro de 1949, Decreto no 35.178/54 (DOU-15 de março de 1954).

\section{Artigo 12}

As Autoridades Aeronáuticas de ambas as Partes Contratantes resolverão, de comum acordo, toda questão referente à interpretação e aplicação deste Acordo, e de seu Anexo. Quando isto não for possível, submeterão o assunto a um Juízo Arbitral, órgão ou entidade, à escolha das mesmas Partes Contratantes.

As Partes Contratantes comprometem-se a conformar-se com as medidas provisórias que possam ser tomadas por esse Juízo Arbitral no curso do litígio, assim como com a decisão arbitral, considerando esta em todo caso definitiva. 
3.3.2 - Brasil-Suíça, firmado em Berna a 10 de agosto de 1948, Decreto no 27.950/50 (DOU-8 de julho de 1950).

\section{Artigo VII}

As divergências entre as Partes Contratantes, relativas à interpretação ou aplicação do presente Acordo ou de seu Anexo, que não estiverem sujeitas às normas prescritas no capítulo XVIII da citada Convenção sobre Aviação Civil Internacional, então puderem ser resolvidas por meio de consulta direta deverão ser submetidas a um Juízo Arbitral, órgão ou entidade, à escolha das mesmas Partes Contratantes.

\subsection{3 - Brasil-Itália, assinado em Roma, a 25 de janeiro de 1951, Decreto no 31.419/52 (DOU-18 de setembro de 1952).}

\section{Artigo 10}

As divergências entre as Partes Contratantes sobre a interpretação ou a aplicaçāo do presente Acordo e do seu Anexo, quando não estiverem sujeitas às normas prescritas no Capítulo $18 \mathrm{da}$ Convenção de Chicago, e não puderem ser resolvidas por meio de consultas diretas, serão submetidas à decisão de um Juízo Arbitral, órgão ou entidade, à escolha das mesmas Partes Contratantes. Caso tais procedimentos não forem possíveis, serão elas submetidas a um Tribunal Arbitral de três membros, dois dos quais nomeados respectivamente por uma e pela outra Parte Contratante, sendo o terceiro designado pelo Presidente do Conselho da Organização de Aviação Civil Internacional que o escolherá entre pessoas incluídas na lista de árbitros prevista pelo Regulamento da OACI e que não tenham a nacionalidade de qualquer das Partes Contratantes.

As Partes Contratantes comprometem-se a conformar-se com as decisões arbitrais que, em qualquer caso, serão consideradas como definitivas.

3.3.4 - Brasil-Japão, assinado no Rio de Janeiro a 14 de dezembro de 1956, Decreto no 51.605/62 (DOU-4 de dezembro de 1962).

\section{Artigo IX}

1. Se surgir qualquer divergência entre as Partes Contratantes relativa a interpretação ou aplicação do presente acordo, as Partes 
Contratantes primeiramente se esforçarão por resolvê-la mediante negociação.

2. Se as Partes Contratantes não chegarem a uma solução por negociaçāo:

a) Podem convir em submeter a divergência a um tribunal arbitral designado por entendimento mútuo, ou a alguma outra pessoa ou órgão, para que seja emitido um parecer consultivo, ou

b) se não concordarem com isso ou se, tendo concordado em submeter a divergência a um tribunal arbitral, não puderem chegar a acordo quanto à sua composiçāo, qualquer Parte Contratante poderá submeter a divergência ao Conselho da Organização de Aviação Civil Internacional, para que seja emitido um parecer consultivo;

c) As Partes Contratantes envidarão todos os esforços possíveis, conforme os meios de que dispuserem para dar cumprimento à opinião expressa em qualquer parecer dessa natureza.

\subsection{5 - Brasil-Alemanha Federal, assinado no Rio de Janeiro a 29 de agosto de 1957, Decreto no 54.173/64 (DOU-26 de agosto de 1964).}

\section{Artigo 12}

1. Excetuadas as disposiçōes em contrário deste Acordo, qualquer divergência entre as Partes Contratantes relativa à interpretação ou aplicação do mesmo, que não puder ser resolvida mediante consulta, será submetida a uma comissāo mista de três membros, dos quais um será designado por cada Parte Contratante e o terceiro escolhido pelos dois primeiros, desde que não seja nacional de qualquer das Partes Contratantes. Cada Parte Contratante designará seu representante dentro de sessenta dias contados da data de entrega, feita por qualquer delas, de uma nota diplomática que solicite apreciação da divergência. $O$ terceiro membro será escolhido dentro de trinta dias após a expiração do prazo de sessenta dias.

2. Se qualquer das Partes Contratantes deixar de designar seu representante dentro do prazo indicado ou se o terceiro membro não houver sido escolhido dentro do limite de trinta dias, qualquer das Partes Contratantes poderá solicitar ao Presidente do Conselho da OACI que faça a designação do membro ou membros necessários para completar a comissão. 
3. As Partes Contratantes envidarão seus melhores esforços dentro dos limites de seus poderes para dar cumprimento ao parecer da comissão escolhida. Cada Parte Contratante se responsabilizará pelos gastos resultantes da atividade de seus representantes, bem como pela metade dos outros gastos.

\subsection{6 - Brasil-México, assinado na Cidade do México a 17 de ou- tubro de 1966, Decreto no 67.697 de 3 de dezembro de 11170 (DOU-7 de dezembro de 1970).}

\section{Artigo 11}

1. Salvo disposição em contrário, qualquer divergência entre as Partes relativas à interpretação ou aplicação do presente Acordo, que não puder ser resolvida por meio de consultas, será submetida, para fins de parecer consultivo, a um Tribunal de três árbitros, sendo um designado por cada uma das Partes e o terceiro pelos dois árbitros assim escolhidos, com a condição de que o terceiro árbitro não seja nacional de nenhuma das Partes. Cada uma das Partes designará um árbitro dentro do prazo de 2 meses a contar da data da apresentação, por uma das Partes à outra de uma Nota diplomática, solicitando o arbitramento de uma divergência; o terceiro árbitro será escolhido decorrido um mês após o citado período de 2 meses.

2. Se qualquer das Partes deixar de designar seu próprio árbitro no prazo de 2 meses, ou se não se chegar à designação do terceiro árbitro dentro do prazo indicado, qualquer das Partes poderá solicitar ao Presidente da Corte Internacional de Justiça que proceda à designação ou designaçōes que forem necessárias, mediante a seleção de árbitro ou árbitros.

3. As Partes envidarão o melhor de seus esforços, no limite de suas faculdades, para pôr em prática a opinião exarada em dito parecer consultivo. Cada parte arcará com a metade dos gastos do Tribunal arbitral.

\footnotetext{
3.3.7 - Brasil-Dinamarca. Decreto no 66.237/70 (DOU-23 de l evereiro de 1970). art. 14 ${ }^{(19)}$.

3.3.8 - Brasil-Suécia, Decreto n 65.813/69 (DOU-10 de dezembro de 1969) art. 14(19).
}

(19) Incorporam as regras do art. 85 da Convençāo de Chicago de 1944. 
3.3.9 - Brasil-Noruega, Decreto no 66.238/70 (DOU-23 de fevereiro de 1970) art. $14^{(19)}$

3.3.10 - Brasil-Países Baixos, Decreto no 26.900/49 (DOU-25 de agosto de 1949).

3.3.11 - Brasil-Turquia, Decreto n- 30.693/52 (DOU-3 de abril de 1952); repete os termos do acordo Brasil-Suíça.

3.3.12 - Brasil-Portugal, Decreto no 35.902/54 (DOU-26 de outubro de 1954); seu art. VIII é idêntico ao do Acordo Brasil-Suíça.

3.3.13 - Brasil-Paraguai, Decreto no 35.543/54 (DOU-28 de maio de 1954); seu art. IX é idêntico ao do Acordo Brasil-Suíça.

3.3.14 - Brasil-França, Decreto no 27.538/49 (DOU-30 de dezembro de 1949); idêntico ao do Acordo Brasil-Suíça.

\section{4 - Sobre Cooperação Tecnológica e Usos Pacíficos da Energia Nu- clear}

3.4.1 - Brasil-Alemanha Federal, Acordo Geral de Cooperação nos Setores da Pesquisa Científica e do Desenvolvimento Tecnológico, assinado em Bonn a 9 de junho de 1969, Decreto $n^{\circ} 65.160$ (DOU-17 de setembro de 1969).

\section{Artigo 12}

1. As divergências surgidas quanto à interpretação ou à aplicação deste Acordo serão dirimidas sempre que possível pelas Partes Contratantes.

2. Caso não seja possível dirimir uma divergência por negociação direta, cada Parte Contratante pode exigir que a divergência seja submetida à decisão da Corte Permanente de Arbitragem da Haia.

3.4.2 - Brasil-Alemanha Federal, Convênio sobre a Entrada de Navios Nucleares em Águas Brasileiras e Sua Permanência em Portos Brasileiros, firmado em Brasília, a 7 de junho de 1972, Decreto no $74.600 / 74$ (DOU-25 de setembro de 1974). 
Artigo 10

1. As Partes Contratantes procurarão resolver por via diplomática qualquer controvérsia eventualmente provocada pela interpretação ou aplicação do presente Convênio e, para esse fim, levarão em conta, primordialmente, as disposições da Convenção de Bruxelas no que concerne à responsabilidade por danos nucleares.

2. Se uma controvérsia não puder ser dirimida por essa forma, será submetida, por petição de uma das Partes Contratantes, a um tribunal arbitral.

3. O tribunal arbitral se constituirá, quando as circunstâncias o exigirem, de forma que cada Parte Contratante designe um membro e os dois membros se porão de acordo para escolher como presidente um cidadão de um terceiro Estado, o qual será nomeado pelos Governos das duas Partes Contratantes. Os membros'serão designados no prazo de dois meses e o Presidente no de três meses, a partir da notificação de uma Parte Contratante à outra de que deseja submeter a controvérsia a um tribunal arbitral.

4. Se os prazos previstos no item 3 não forem observados, cada Parte Contratante poderá, na ausência de outro acordo, solicitar ao Presidente da Corte Internacional de Justiça que proceda às designaçōes necessárias. Caso o Presidente seja cidadão de uma das Partes Contratantes ou se encontre impedido por outra causa, caberá ao seu substituto efetuar as designaçōes. Se este também for cidadão de uma das Partes Contratantes ou se também se encontrar impedido, as designaçōes competirāo ao membro da Corte Internacional de Justiça que siga imediatamente na ordem hierárquica e não seja cidadão de uma das duas Partes Contratantes.

5. O tribunal arbitral tomará suas decisōes por maioria de votos. Cada Parte Contratante custeará os gastos de seu membro e de sua representação no processo arbitral. Os gastos do Presidente e os demais gastos serão custeados em partes iguais pelas duas Partes Contratantes. O tribunal arbitral poderá adotar outra distribuição dos gastos. Nos demais, o tribunal arbitral adotará seu próprio regulamento.

3.4.3 - Brasil-Alemanha Federal, Acordo sobre Cooperação no Campo dos Usos Pacíficos da Energia Nuclear, assinado em Bonn, a 27 de junho de 1975, Decreto no 76.695/75 (DOU-2 de dezembro de 1975). 
Artigo 8

(1) As Partes Contratantes empenhar-se-ão para solucionar divergências sobre a interpretação do presente Acordo por via diplomática.

(2) Quando as divergências nāo puderem ser solucionadas da maneira acima, adotar-se-āo processo de arbitragem previsto no Artigo 10 do Acordo sobre a Entrada de Navios Nucleares em Águas Territoriais Brasileiras e sua Estada em Portos Brasileiros, concluído entre as Partes Contratantes em 7 de junho de 1972.

\section{5 - Sobre Garantia de Investimentos, assinado em Washington, a 6 de fevereiro de 1965, Decreto $n^{\circ}$ 57.943/66 (DOU-16 de março de 1966).}

\section{Artigo VI}

1. Divergências entre os dois Governos relativas à interpretaçāo das disposições deste. Acordo serão resolvidas, na medida do possível, por meio de negociações entre os mesmos. Se determinada divergência não puder ser resolvida dentro de um período de seis meses subseqüente à solicitação de tais negociações, a mesma poderá ser submetida, a pedido de qualquer um dos Governos, a arbitramento, de acordo com o parágrado 4 deste Artigo.

2. Qualquer reivindicação concernente a um investimento garantido de conformidade com o presente Acordo, contra qualquer dos Governos, que possa constituir matéria de Direito Internacional Público, será, a pedido do Governo que formule a reivindicação, submetida a negociações. Se, ao fim de seis meses subseqüentes ao pedido de negociaçōes, os dois Governos não resolverem a reivindicação por acordo mútuo, a mesma, inclusive se a questão constitui ou não matéria de Direito Internacional Público, será submetida a arbitramento de acordo com o parágrago 4 deste Artigo.

3. Serão excluídas das negociaçōes e do procedimento arbitral, aqui contemplados, os assuntos que permaneçam exclusivamente dentro da jurisdição interna de um Estado Soberano. Em conseqüência, fica entendido que reivindicaçōes decorrentes de desapropriação de bens de investidores privados estrangeiros não apresentam questōes de Direito Internacional Público a nāo ser e até que o processo judicial do País Recipiente tenha sido exaurido e se configure uma denegação de justiça, na forma em que tais 
termos são definidos no Direito Internacional Público. O valor em dinheiro de qualquer reivindicação submetida para negociação ou arbitramento nos termos deste acordo, não deverá exceder à importância da compensação paga por força de garantias concedidas, em conformidade com este Acordo, com relação ao investimento objeto de reivindicação.

4. Questões surgidas nos termos dos parágrafos 1,2 e 3 deste Artigo serão submetidas, a pedido de qualquer dos Governos, a um tribunal arbitral que se pautará pelos princípios do Direito Internacional Público, reconhecidos nos Artigos 1\% e 2o do Tratado Geral Interamericano de Arbitramento, assinado em Washington, em 5 de janeiro de 1929. Somente os respectivos Governos podem requerer o processo arbitral e do mesmo participar. A escolha de árbitros e o método do seu procedimento obedecerão ao disposto nos Artigos 3 , 4, 5 e 6 do Tratado Geral de Arbitramento de 1929. O caráter final das decisōes do Tribunal Arbitral e o método para sua interpretação deverāo obedecer às disposições do Artigo $7^{\circ}$ daquele Tratado.

\section{Conclusōes}

Estabelecer relações causais entre o hermetismo dos tratados existentes na América Latina e sua possível aplicação, não parece ser a atitude adequada para uma análise das soluções pacíficas de litígios na região. Se hermetismo quer significar abrangência entre as partes envolvidas, o que levaria à maior aplicação das normas vigentes entre elas, (e portanto os tratados bilaterais teriam maior possibilidade de produzir seus efeitos, que os multilaterais) o conceito não serve para explicar o relativo vigor dos tratados multilaterais de integração econômica na América Latina. Por outro lado, se hermetismo quer significar não uma generalização mas, antes, especialização de assuntos versados, (e, portanto, os tratados que versassem sobre assuntos tópicos teriam maior eficácia que os tratados de grandes temas e soluçōes generalizadas), também parece ser inservível, pois o tratado de arbitragem institucional sob a égide do Banco Mundial, para solução de litígios em matéria de investimentos internacionais, não foi assinado por quaisquer Estados da América Latina.

Falar-se em hermetismo, tão-só a partir do exame dos tratados vigentes, parece ser uma atitude pouco realista e algo simplista. Antes, é necessário examinar a real vontade dos Estados latinoamericanos em aplicar as normas que eles mesmos criam, verificar as condiçōes de sua aplicabilidade, bem como as condiçōes para uma continuidade de propósitos dos Governos que se sucedem.

Por outro lado, é mister considerar a mudança radical de enfoque verificado na concepção atual do Direito Internacional Público: nāo mais um con- 
junto de normas proibitivas para assegurar a paz, mas, antes, um conjunto de normas mandamentais que asseguram a paz de maneira indireta, ao construir um edifício normativo de soluções cada vez mais criativas e integracionistas.

$\mathrm{Na}$ verdade, o Direito Internacional Público foi uma criação originariamente elaborada na Europa a partir do Século XVI; a América Latina, ao emergir nas relaçōes internacionais, encontrou-o pronto e a ele se amoldou. Com a emergência de um sem número de Nações da Ásia e da África, com a existência de foros diplomáticos novíssimos, tais os organismos internacionais, um novo $\mathrm{Di}$ reito Internacional Público do Desenvolvimento tem aparecido, em substituição àquele, "direito esse derivado não da autoridade racional, mas de uma atitude carismática dos países do Terceiro Mundo junto à opinião pública mundial"'(20).

Por outro lado, um desafio existe e se baseia no princípio de que um valor só desaparece por substituição por outro, ou por morte natural (por perder suas características de valer e, assim, não mais ter os atributos de respeito e oponibilidade aos indivíduos). Ora, substituir os valores do Direito Internacional Público por uma retórica vazia e sem possibilidade de tornar-se norma (o risco do terceiro-mundismo) é atitude tão irrealista quanto imprudente, pois aqueles valores ainda estão vigentes e são eficazes na comunidade dos Estados na atualidade.

Tal desafio é o grande tema que se coloca à América Latina, de saber conviver com as normas elaboradas por Estados outros a partir do Século XVI, saber como modificá-las no seu benefício, e, eventualmente, saber como trazer sua contribuição às discussões contemporâneas para a emergência de um Direito Internacional do Desenvolvimento.

\section{BIBLIOGRAFIA}

AlbuQuerQue mello, Celso D. Direito Internacional Público, Rio de Janeiro, São Paulo, Biblioteca Jurídica Freitas Bastos, $8^{\text {a }}$ edição revista e aumentada, 1986.

ASSOCIATION Henri Capitant des Amis de la Culture Juridique Française L'Effectivité des Décisions de Justice, (jornadas francesas de Paris e Aix-en-Provence), Paris, Economica, 1987.

(20) Patricia Buirette-Maurau, La Participation du Tiers-Monde à l'Elaboration du Droit International, Paris, Libraire Générale de Droit et de Jurisprudence, 1983, p. 27 e ss. 
BUIRETTE MAURAU, Patricia La Participation du Tiers-Monde à l'Élaboration du Droit International, Paris, Librairie Générale de Droit et de Jurisprudence, 1983.

IRALA BURGOS, Jerónimo "Los Acuerdos de Itaipu, Yacireta y Corpus sobre la Explotación de los Recursos Hidroelétricos del Rio Paraná: una Nueva Forma de Cooperación Internacional en la Cuenca del Prata, entre Paraguay, Brasil y Argentina", Assunção, Faculdade de Direito da Universidade Católica, 1983, sem indicação de editor.

NATTIER, Frank E. "International Commercial Arbitration in Latin America: Enforcement of Arbitral Agreements and Awards", in Texas International Law Journal, 1986, vol. 21, no 3.

RANGEL, Vicente Marotta "Soluçōes Pacíficas de Controvérsias: Impacto das Organizações Internacionais" in Anuário Jurídico Interamericano, Washington, Organização dos Estados Americanos, 1985.

SOARES, Guido Fernando Silva Das Imunidades de Jurisdição e de Execução, São Paulo, Forense, 1983.

SOARES, Guido Fernando Silva "Introdução Histórica ao Estudo das Soluções Pacíficas de Litígios e das Arbitragens Comerciais Internacionais" in Revista da Faculdade de Direito da Universidade de São Paulo, São Paulo, ed. da Revista da FADUSP, 1976, vol. LXXI.

STEIN, Eric "Impact of New Weapons Technology in International Law" in Recueil des Cours da Academia de Direito Internacional da Haia, Haia, 1971, tomo 133, vol. II.

STOESSINGER, J.G. The Might of Nations, World Politics in Our Times, Nova York, Random House, 1967.

STRAUS, Donald B. "Report of the Vice President of the Interamerican Commercial Arbitration Commission" in VI Conferência Interamericana sobre Arbitragem Comercial Internacional, OEA, Rio de Janeiro, abril de 1976.

YEPES, M.J. Philosophie du Panaméricanisme et Organisation de la Paix, Neuchâtel, Editions de la Baconnière, 1945. 